Conciliador

Letras e

Direito

Mediação

Linguística

Forense

Conciliação

Língua

Falada

Comunicação

Interação

verbal

Mediador

Análise da

Conversação

Acordo

Neurolinguística

Justiça

Solução de

conflitos

Linguagem

Cultura

de paz

Pragmática

Psicolinguística

Semântica

Estudos

Linguísticos

ESTRATÉGIAS LINGUISTICAS E PARALINGUISTICAS COMO MEIOS FACILITADORES PARA APLICACÃO DAS TÉCNICAS DE MEDIAÇ̃̃O E CONCILIACCÃO

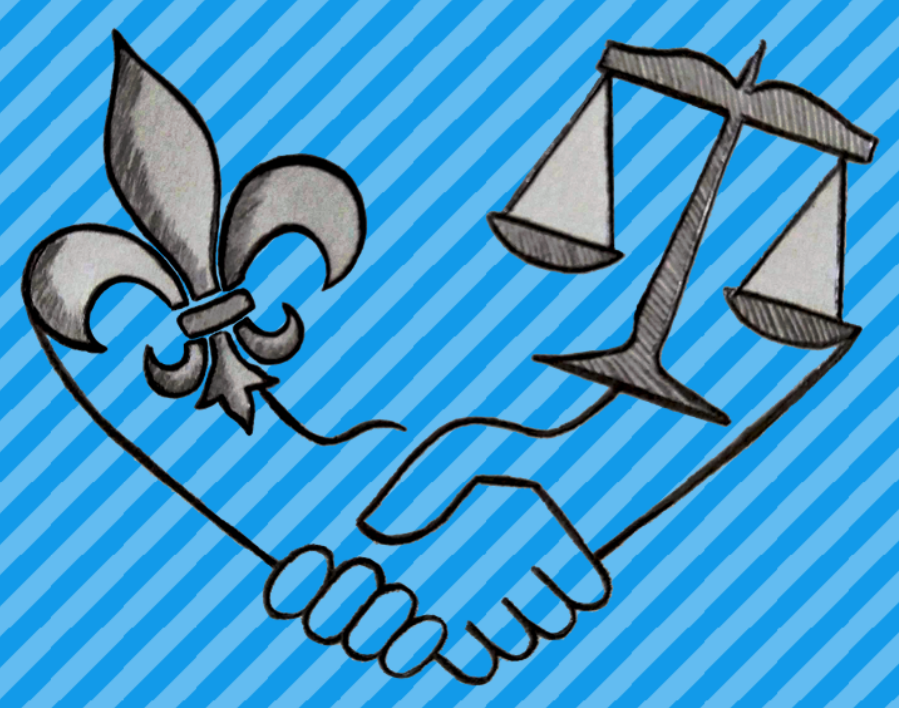




\section{ESTRATÉGIAS LINGUÍSTICAS E PARALINGUÍSTICAS COMO MEIOS FACILITADORES PARA APLICAÇÃO DAS TÉCNICAS DE MEDIAÇÃO E CONCILIAÇÃO}

\section{CLAUDIA POLIANA DE ESCOBAR DE ARAUJO}


Dados Internacionais de Catalogação na Publicação (CIP) (Even3 Publicações, PE, Brasil)

AR658e ARAUJO, Claudia Poliana de Escobar.

Estratégias linguísticas e paralinguísticas como meios facilitadores para aplicação das técnicas de mediação e conciliação / Claudia Poliana de Escobar Araujo. - 1. ed. Recife: Even3 Publicações, 2019.

1 livro digital ; $62 \mathrm{p}$.

Bibliografia.

Capa: Letícia de Escobar de Araujo.

ISBN: 978-85-572-2311-0

1. Linguística. 2. Análise da Conversação. 3. Mediação e Conciliação. I. Título.

CDD 410

CDU 808 


\section{Sumário}

INTRODUÇÃOO

1. INTERAÇÃO VERBAL: ELEMENTOS DE ORGANIZAÇÃO DO TEXTO FALADO

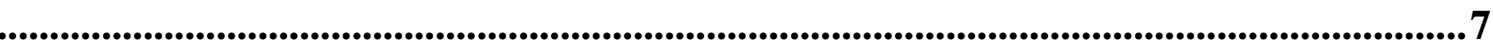

1.1. INTERAÇÃO VERBAL: ESTRATÉGIAS SOCIOINTERACIONAIS E

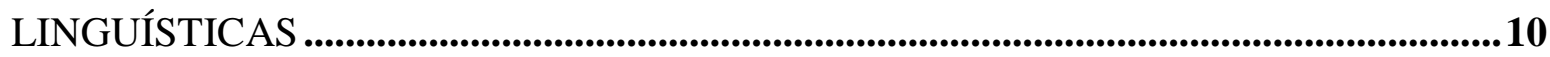

2. O CONTEXTO: AUDIÊNCIAS DE MEDIAÇÃO E CONCILIAÇÃO .............................13

3. TÉCNICAS DE MEDIAÇÃO E CONCILIAÇÃO E O ROL DE ESTRATÉGIAS LINGUÍSTICAS E PARALINGUÍSTICAS ......................................................................14

3.1 Recontextualização (ou paráfrase) ............................................................................14

3.2 Escuta ativa - audição de propostas implícitas ...........................................................16

3.3 Afago (ou reforço positivo) ............................................................................................20

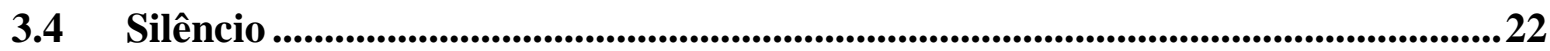

3.5 Sessões privadas ou individuais .............................................................................23

3.6 Inversão de papéis....................................................................................................25

3.7 Geração de opções/perguntas orientadas a geração de opções...............................27

3.8 Normalização.................................................................................................................30

3.9 Organização de questões e interesses ..........................................................................32

3.10 Enfoque prospectivo .................................................................................................34

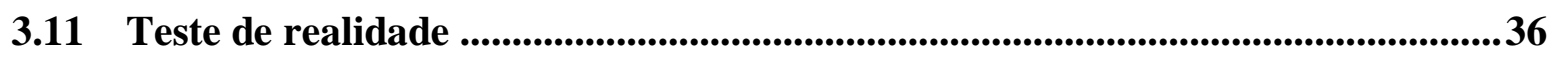

3.12 Validação de sentimentos ..............................................................................................38

4. OUTRAS SUGESTÕES PARA MOMENTOS DIVERSOS DA MEDIAÇÃO E CONCILIAÇÃ

4.1 SIMPLIFICAÇÃO DA LINGUAGEM …..........................................................45

4.2 COMUNICAÇÃO EMPÁTICA ...............................................................................46

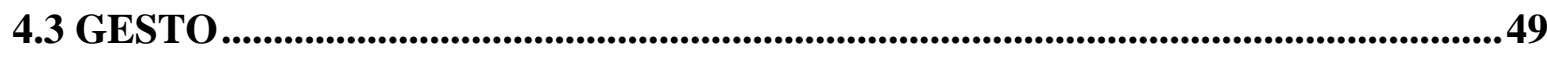

5. PRÉVIA COM ADVOGADOS E DECLARAÇÃO DE ABERTURA...........................52

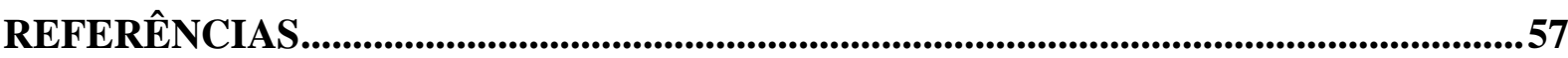




\section{LISTA DE QUADROS}

Quadro 1 - Dicas para recontextualização (paráfrase)............................................................. 14

Quadro 2 - Dicas para Escuta ativa - audição de propostas implícitas ....................................17

Quadro 3 - Dicas para Afago (ou reforço positivo).............................................................21

Quadro 4 - Dicas para técnica do Silêncio .......................................................................22

Quadro 5 - Dicas para usar nas sessões individuais ...........................................................23

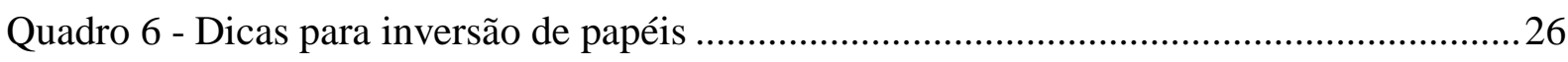

Quadro 7 - Dicas para geração de opções.........................................................................28

Quadro 8 - Dicas para normalização do conflito ................................................................... 31

Quadro 9 - Dicas para organização de questões e interesses..................................................32

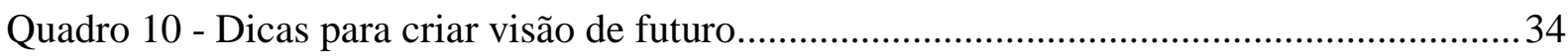

Quadro 11 - Motivações para mudança de comportamento e enfoque prospectivo ..................36

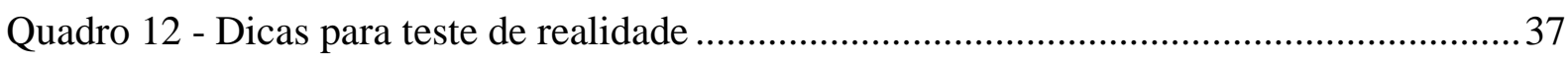

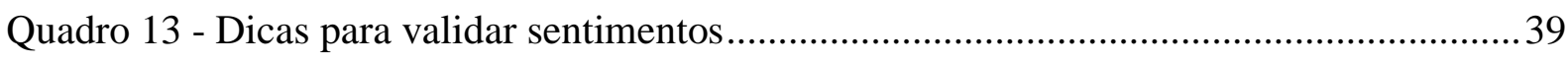

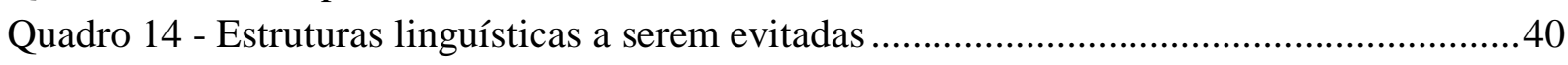

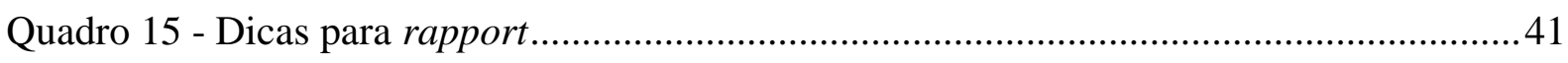

Quadro 16 - Exemplos de Marcadores Discursivos ............................................................42

Quadro 17 - Sugestões para iniciar a audiência de Mediação e Conciliação ............................44

Quadro 18 - Sugestões de sinônimos e palavras com acepção positiva ...................................45

Quadro 19 - Sugestões de sinônimos para facilitação da linguagem .......................................46

Quadro 20 - Listagem de sentimentos - Comunicação Não Violenta........................................46

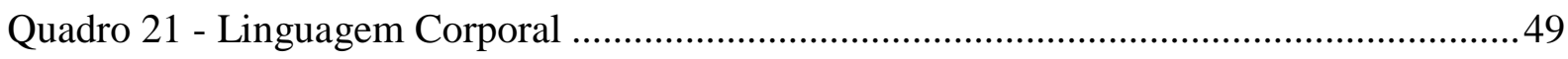




\section{AGRADECIMENTOS}

À CAPES, por financiar parcialmente o desenvolvimento deste trabalho. "O presente trabalho foi realizado com apoio da Coordenação de Aperfeiçoamento de Pessoal de Nível Superior - Brasil (CAPES) - Código de Financiamento 001”.

À minha orientadora e professora Dr. Vanessa Hagemeyer Burgo, pela confiança e apoio.

Ao professor Wagner Corsino e à professora Cristiane Rodrigues pelo incentivo à pesquisa e pelas valiosas contribuições na etapa inicial desse projeto.

Aos meus amigos, colegas e alunos do Projeto de Ensino de Graduação "Estratégias linguísticas empregadas nas soluções consensuais de litígios: mediação e conciliação”, por toda dedicação e contribuição para o desenvolvimento desta pesquisa.

Aos meus pais e minha irmã por me fortalecerem e estarem sempre comigo.

Aos meus amigos e todos que de alguma forma me apoiaram nessa trajetória. 


\section{INTRODUÇÃO}

A comunicação é inerente ao ser humano, seja verbal ou não, nas modalidades faladas ou escritas. Utilizamos a comunicação para interação, manifestação das emoções e dos pensamentos, bem como para resoluções de conflitos, dos quais, muitas vezes, podem ocorrer durante uma interação verbal. Nessa perspectiva, este trabalho tem como objetivo apontar algumas características principais da organização da comunicação falada, ou seja, da interação verbal, assim como traçar um caminho interdisciplinar com foco no uso consciente da linguagem e, contribuir, especialmente, com a prática de mediadores e conciliadores judiciais, ou extrajudiciais para resolução de conflitos.

Dado o exposto, elaboramos uma amostra de estruturas linguísticas que poderão ser utilizadas para facilitar a aplicação das técnicas de mediação ${ }^{1}$; porém, cabe salientar que, conforme relatado, o papel desse rol (amostra) é exemplificar e relacionar as teorias linguísticas às técnicas de mediação/conciliação. Posto que não é um material prescritivo, visto que não podemos descartar o estilo individual de uso da língua e os diversos contextos que podem ocorrer durante a mediação. Portanto, trata-se de um material instrucional composto por reflexões linguísticas e exemplos de uso conforme as técnicas de mediação.

Tivemos como base para este rol, Brasil (2016) - Manual de Mediação Judicial do CNJ (Conselho Nacional de Justiça), organizado pelo professor Dr. André Gomma de Azeredo, no qual são indicadas doze técnicas e/ou ferramentas para provocação de mudanças, a serem utilizadas nas audiências de mediação e conciliação, a saber: escuta ativa, recontextualização (ou paráfrase), afago, silêncio, sessões individuais, inversão de papéis, geração de opções, normalização, organização de questões e interesses, enfoque prospectivo, teste de realidade, e validação de sentimentos.

Com o suporte das técnicas citadas e outros procedimentos da mediação, tais como: a declaração de abertura, criação do rapport, ambiente positivo, linguagem simplificada e positiva -, que caracterizam, também, a relação interpessoal -, utilizamos conhecimentos de teorias linguísticas, como: Análise da Conversação (MARCUSCHI, 1986; KERBRATORECCHIONE, 2006), Pragmática (GOFFMAN, 1967, 1974; BROWN E LEVINSON, 1987), Neurolinguística (MEIRELLES, 2017), Psicolinguística (SLOBIN, 1980), Linguística Textual (KOCH, 2016) e Argumentação (KOCH, 2011, 2017) - Argumentação tratada numa

\footnotetext{
${ }^{1}$ Toda vez que nos referirmos à mediação estamos também referindo-nos a conciliação, pois com relação às técnicas, há a possibilidade de serem aplicadas em qualquer uma das alternativas para resolução de conflito.
} 
perspectiva linguística com base na Semântica Argumentativa (Ducrot) e estudos do texto para sugerir "modos" de dizer, ou seja, nossa preocupação é mostrar uma forma de "como" dizer o que precisa ser dito dentro da mediação, buscando sempre uma comunicação leve e positiva.

Além do exposto, procuramos apontar alguns conhecimentos da Comunicação Não Violenta (ROSENBERG, 2006) e Comunicação gestual (WEIL, 2011), isto é, não verbal/paralinguística ${ }^{2}$, oriundos da Psicologia -, ainda que nosso foco seja a Linguística, esses conhecimentos fazem parte de um conjunto para falarmos e compreendermos a língua numa perspectiva empática, associados ao contexto de uso e à linguagem corporal dos interlocutores.

Optamos por evitar a linguagem técnica de qualquer uma das áreas citadas, visto que nosso objetivo é facilitar a informação, evitar jargões e simplificar a linguagem, em razão de consideramos o ambiente da mediação um espaço que acolhe todos os perfis sociais, independentemente de nível de escolaridade e/ou classe social. Assim, nossa intenção não é tratar do assunto de uma forma simplista ou desmerecer nenhuma das áreas, nem o contexto jurídico, em que a mediação está inserida, todavia, visamos à clareza e à facilitação da comunicação. Com tal intento, consideramos a norma padrão ${ }^{3}$ da Língua Portuguesa, no entanto, preferimos utilizar estruturas não muito formais e próprias da língua falada, uma vez que um dos princípios que regem a mediação e conciliação é a oralidade e, além disso, é importante que as partes se sintam à vontade, em um ambiente cortês e natural.

\footnotetext{
${ }^{2}$ Entendemos como paralinguísticos os sons, entonação e até o olhar que acompanham a fala do emissor, além disso, temos estratégias extralinguísticas que estão no âmbito da linguagem corporal, como a postura, posicionamento dos braços, entre outros.

${ }^{3}$ Respeito às normas ortográficas vigentes e à prescrição da gramática tradicional, porém, sem utilizar linguagem rebuscada.
} 


\section{INTERAÇÃO VERBAL: ELEMENTOS DE ORGANIZAÇÃO DO TEXTO FALADO}

De modo geral, a interação verbal foi por um tempo tratada como uma forma de expressão informal, sem regras, ou seja, considerada como um desvio da norma padrão e da escrita. Entretanto, esse julgamento tem perdido força para os Estudos da Língua Falada, especialmente na linha de pesquisa da Análise da Conversação, na qual temos trabalhos significativos, como Marcuschi (1986), Castilho (2014), Jubran (2015), Koch (2015), que evidenciam a construção do texto falado, com base na sua organização e efeitos de sentido.

Consideramos a língua falada como um mecanismo organizado de interação, com base nessa visão, abordaremos os principais elementos e características da língua falada, assim como seus efeitos de sentido nos contextos empregados. Nesse estudo, buscamos relacionar as técnicas de mediação e conciliação às estratégias linguísticas, por meio da descrição e exemplificação de estruturas linguísticas e seus possíveis impactos diante dos interactantes 4 .

Cabe evidenciar que o fluxo de informação na língua falada é diferente da escrita, pois diferentemente desta o planejamento daquela é instantâneo, conforme salienta Urbano (1998), o planejamento é local e as tarefas cognitiva e verbal ocorrem ao mesmo tempo, podendo ocorrer marcas linguísticas desse planejamento simultâneo ou outras estratégias para a construção das ideias. Dessa forma, a seguir, apontaremos tais marcas de planejamento e de organização do texto falado, que caracterizam a construção da interação verbal, tal como recursos e ferramentas utilizados pelos falantes para atingir seus objetivos.

\section{Interações simétricas e assimétricas}

Estes tipos de interações estão associados à ideia de direito à voz e escolha do tema, da forma como é conduzida a interação e/ou diálogo. De acordo com Marcuschi (1986), o diálogo simétrico é aquele no qual os falantes possuem os mesmos direitos com relação aos pontos citados acima, como exemplo, o diálogo entre amigos, as conversas informais no ambiente de trabalho - são interações simétricas; já o diálogo assimétrico ocorre quando um dos interactantes possui o direito de iniciar, indicar o direito à fala de outro participante, ou seja, exercer pressão sobre os outros participantes, como no caso de entrevistas e depoimentos, nos quais temos uma pessoa que possui o poder de elencar o tema da conversa e, quem fala e quando fala.

\footnotetext{
${ }^{4}$ Referimo-nos aos falantes que participam de uma conversa, o emissor e receptor das mensagens trocadas.
} 


\section{Turno conversacional}

De forma geral, o direito a voz e/ou a vez de falar é o que chamamos de turno conversacional. Para Castilho (2014, p. 36), "o turno é a unidade da conversação, é o segmento produzido por um falante com direito a voz". Nesse sentido, o autor problematiza a questão de o turno ser qualquer segmento produzido por um falante ou se podemos considerálo apenas como segmento produzido quando o falante tem direito a voz. Em nosso estudo, o turno é considerado, de forma ampla, todo segmento produzido por um falante, independentemente se ele possui direito a voz ou interrompeu outro falante, por exemplo, seguindo o entendimento de Sacks, Schegloff e Jefferson (1974).

\section{Manutenção e passagem de turno}

Conforme mencionado, consideramos como turno os segmentos produzidos por um falante, e esses segmentos ou direito a voz exigem mecanismos para serem mantidos ou passados a outro falante. A manutenção do turno, geralmente, ocorre por meio de marcadores discursivos, elementos como: uhuu...; ah sim..., entre outras estratégias que exploraremos adiante. A passagem do turno pode ocorrer de duas formas, consentida ou "tomada", isto é, uma forma amigável e outra nem tanto.

Nesse sentido, a passagem consentida acontece quando o falante oferece dicas ao seu interlocutor de que está passando sua vez de falar. Como exemplificação: pode ser por meio de silêncio, de uma expressão linguística ou de um olhar. A tomada de turno sem consentimento ocorre quando interrompemos nosso interlocutor e passamos ter o direito a fala. Nesse caso, pode ocorrer sobreposição de vozes, já que pode permanecer mais de uma pessoa falando ou quando um indivíduo recua para o outro continuar sua fala.

\section{Pares adjacentes}

Pares adjacentes ou pares dialógicos são estruturas ligadas à disposição dos turnos, como salienta Castilho (2014, p. 44) são dois turnos emparelhados ${ }^{5}$, ou seja, uma sequência

\footnotetext{
${ }^{5}$ Há controvérsias sobre uma estruturação diferente dos turnos, com sequências inseridas ou uma terceira sequência, todavia, essa discussão não é objetivo desse trabalho, utilizaremos a noção mais comum e de uso mais frequente.
} 
leva a outra. Temos como exemplos de pares adjacentes mais comuns: pergunta/resposta; convite/aceite ou recusa; reclamação/pedido de desculpas/aceite ou recusa, entre outros. Além disso, vale ressaltar que dentre essas estruturas, há sempre uma estrutura preferida ou despreferida, conforme o contexto de uso, pois diante das convenções sociais, muitas vezes, um convite é feito apenas por educação e, dessa forma, não se espera um aceite; já quando alguém pede desculpas, o esperado é que seu pedido seja aceito.

\section{Hesitação}

A hesitação, na interação falada, não é mais vista como fragmentação do texto falado. De acordo com Marcuschi (2015, p. 50), a hesitação tem como característica básica o fato de constituir evidentes rupturas na fala, no entanto não são aleatórias. Um exemplo constante de hesitação na língua falada é quando o falante tem como objetivo moderar sua proposição.

Quanto às manifestações da hesitação, Koch (2016, p. 91-92) salienta que "as hesitações - se manifestam por meio de pausas, preenchimentos ou não, alongamentos de vogais, consoantes ou sílabas iniciais ou finais, repetição de palavras de pequeno porte, truncamentos oracionais etc.”. Estas manifestações apontadas pela autora revelam a função cognitiva do falante para ganhar tempo e planejar sua fala.

\section{Interrupção}

A interrupção ocorre quando há um intervalo na fala de algum emissor. Essa pausa pode realizar-se pelo próprio falante ou pela interferência de um dos seus interlocutores. Segundo Souza-e-Silva e Crescitelli (2015, p. 82), “como fenômeno sinalizador, a interrupção aponta, ainda, para o caráter reflexivo da linguagem, isto é, para a possibilidade que esta tem de poder olhar para si mesma, de se voltar sobre aquilo que acabou de ser dito ou antecipar o que ainda vai ser proferido".

Conforme exposto, podemos considerar alguns pontos de vista distintos relacionados à interrupção. Inicialmente, pode ser considerada uma forma de reflexão do que foi dito e planejador verbal do que será dito. Nesse seguimento, os aspectos podem ser considerados positivos; entretanto, numa situação formal de uma audiência, as interrupções materializadas por terceiros podem ser vistas como falta de respeito ou falta de consideração com quem está falando. Nesse segundo caso, será preciso desenvolver estratégias para tornar esse 
comportamento positivo, pois, ainda que as partes possuam instruções para não interromper a fala um do outro, numa interação comum, é possível que aconteça.

\section{Repetição}

Para Marcuschi (2015, p. 208) a repetição na fala é um processo formulativo, frisando que "repetir as mesmas palavras num evento comunicativo não equivale a dizer a mesma coisa", ou seja, quando nosso interlocutor repete por algumas vezes uma palavra ou certa oração, é sinal de que esta repetição possui um caráter interativo e intencional. A repetição pode ter função argumentativa como, por exemplo, em audiências de mediação e conciliação, as quais podem ser uma pista para compreensão de sentimentos e desejos das partes.

\section{Reformulação}

A reformulação é um processo que pode ocorrer na língua falada por meio da correção e da paráfrase. Esses dois processos possuem características semelhantes de às funções interacionais, conforme Gülich e Kotschi (1987 apud Fávero, Andrade e Aquino, 2015) são produzidos por problemas do processo interativo e que pretendem ser reparados de alguma forma, seja para garantir a compreensão dos enunciados, seja para atender às normas de boa conduta na interação - normas essas que trataremos no terceiro tópico "Técnicas de mediação e conciliação e o rol de estratégias linguísticas e paralinguísticas".

A correção ocorre quando o falante tem a intenção de reformular algo já dito, uma vez que julga sua proposição inadequada para o contexto. Essa inadequação pode decorrer do conteúdo que foi proferido ou pelo modo como foi proferido, a depender da intenção comunicativa do emissor.

O parafraseamento, também considerado um processo reformulativo, normalmente, ocorre pela reorganização do que foi dito, considerando novas estruturas da língua, entretanto, sua característica principal é que mantenha a equivalência de sentido da informação, diferentemente da correção, que há possibilidade de mudança de sentidos.

\subsection{INTERAÇÃO VERBAL: ESTRATÉGIAS SOCIOINTERACIONAIS E LINGUÍSTICAS}


Diante de uma perspectiva social e interacional da língua, vale ressaltar a relação da construção do texto falado com a Pragmática Conversacional, as quais nos darão subsídios para descrição dos efeitos de sentidos referentes à interação verbal. Nesse aspecto, abordaremos, também, as questões relacionadas aos trabalhos de face aos elementos de atenuação e polidez/cortesia.

\section{Face}

O conceito de face, exposto por Goffman (1967), é o valor social positivo que uma pessoa efetivamente reivindica para si por meio da linha de ação que os outros pressupõem que ela tenha adotado durante um contato específico, isto é, a face/imagem é a forma como queremos que o outro nos veja, seja nas relações pessoais ou profissionais.

Além do conceito de face, há também discussões sobre a face positiva e negativa, ou ainda, atos que ameaçam a face. Esse trabalho não tem como foco teorizar todos esses conceitos, portanto, atentamo-nos, apenas, em chamar a atenção para o fato de que na interação nos preocupamos, na maioria das vezes, em preservar nossa imagem ou a imagem do nosso interlocutor -; ou ainda, a depender do nosso interesse comunicativo, colocamos em risco à imagem do nosso interlocutor, assim como a nossa também pode ser colocada em risco em uma interação real. Nesses últimos casos, quebramos o que Goffman (1967) chamou de contrato social, que seria considerada uma interação cooperativa sem problemas ou conflitos.

\section{Polidez/cortesia}

Em conformidade com as discussões sobre face e contrato social de interações, temos as questões da polidez e cortesia que é de grande influência no desenvolvimento de uma conversação. É possível que em momentos de conflitos, como nos casos das audiências, ainda que as partes possuam interesse em resolver suas pendências, em alguns momentos, podem não conseguir atender aos comportamentos linguísticos, paralinguísticos e sociais esperados na perspectiva da polidez e cortesia.

A polidez pode ser concebida como um conjunto de normas sociais que cada comunidade estabelece para regular o comportamento adequado de seus membros, ajustando atitudes às normas. As formas de polidez estão vinculadas não só a determinada cultura, mas também à língua dessa sociedade (FÁVERO, ANDRADE; AQUINO, 2000, p. 71). 
Conforme exposto, além do comportamento social, podemos perceber as manifestações de polidez e impolidez por meio do uso da língua ou linguagem. Esta é utilizada, nesse trabalho, como qualquer forma de expressão paralinguística ou extralinguística, as quais não são usadas nas interações aleatoriamente, pois, também, refletimos nossas intenções mediante o uso da linguagem. No que se refere à língua, fundamentamo-nos na concepção de língua como sistema organizado de signos, ou seja, o uso verbal da Língua Portuguesa, diferentemente da linguagem como qualquer meio de comunicação, seja paralinguístico (sons, entonação...) ou elementos gestuais.

\section{Marcadores Discursivos}

Os Marcadores Discursivos ${ }^{6}$, doravante MDs, na maioria dos casos, são estruturas explícitas das estratégias e processos de construção do texto falado, além disso, podem dar pistas das intenções comunicativas do falante - mesmo quando implícitas.

Cabe salientar a definição de MDs, em conformidade com Risso; Oliveira-e-Silva e Urbano (2015, p. 371) "trata-se de um amplo grupo de elementos de constituição basicamente diversificada, envolvendo, no plano verbal, sons não lexicalizados, palavras, locuções e sintagmas mais desenvolvidos". Os autores evidenciam, também, que os MDs sinalizam articuladores textuais e relações interpessoais. Nesse sentido, os MDs em conjuntos com as estratégias e procedimentos linguísticos de construção do texto falado, expostos anteriormente, serão nossos principais aliados na articulação da fala dos mediadores e conciliadores, bem como poderão auxiliar na percepção das intenções comunicativas dos falantes (as partes).

\footnotetext{
${ }^{6}$ Priorizamos a nomenclatura de Marcadores Discursivos por considerar que podem abranger todos os tipos de marcadores em qualquer tipo de interação, falada ou escrita, formal ou informal, ainda que o trabalho tenha base na língua falada não utilizaremos "Marcadores Conversacionais".
} 


\section{O CONTEXTO: AUDIÊNCIAS DE MEDIAÇÃO E CONCILIAÇÃO}

Diante dos apontamentos acerca das principais características da organização e desenvolvimento da língua falada e das principais técnicas de mediação e conciliação, a seguir, propomos uma visão geral, evidenciando alguns aspectos fundamentais da configuração desse tipo de interação, com base nos preceitos teóricos que respaldam esse trabalho.

Ao considerar que as audiências de mediação e conciliação são formas alternativas para solução de conflitos, por meio do auxílio de um facilitador - mediador e conciliador, que deve ser imparcial na sua atuação, vale assinalar o caráter assimétrico desse tipo de conversação; visto que há uma pessoa que possui o direito de distribuição dos turnos (direito a voz), esse seria, possivelmente, o desafio inicial do profissional que atua nesse contexto, controlar o impulso dos participantes.

Deve haver a preocupação com a distribuição por igual do tempo de fala entre as partes, como previsto na formação dos mediadores e conciliadores, além disso, é preciso estar atento ao modo como ocorrerá a troca de falantes, para que nenhum se sinta desfavorecido (grifo nosso).

Outros aspectos relevantes são as estratégias propostas neste trabalho tais como: a atenção para as evidências assinaladas pelos marcadores discursivos (ex.: huum, ah, pareceme, quer dizer... então, entre outros), o desenvolvimento de contrato social de bom convívio, em não falar algo para constranger ou expor alguém, e a polidez como uma estratégia de manter a harmonia da interação, porém, as estratégias de polidez não devem ser utilizadas em exagero para não causar estranhamento ou desconforto entre as partes envolvidas e o(a) mediador(a), como no afago pela presença de todos e a importância o advogados, deve ser realizado de forma natural, por exemplo, para que os agradecimentos não pareçam artificiais.

Com base no exposto, as sugestões propostas são fundamentadas em estudos linguísticos de língua falada e seus efeitos de sentido, de acordo com Marcuschi (1986), Kerbrat-Orecchione (2006), Goffman (1967, 1974); Brown e Levinson (1987), Koch (2011, 2016, 2017) . Juntamente com as sugestões de estruturas linguísticas ou paralinguísticas tentamos trazer contribuições de dicas de uso e/ou restrições, especialmente para o mediador ou para interpretação das intenções das partes. 


\section{TÉCNICAS DE MEDIAÇÃO E CONCILIAÇÃO E O ROL DE ESTRATÉGIAS LINGUÍSTICAS E PARALINGUÍSTICAS}

Neste item, apresentamos uma síntese das doze técnicas, especialmente, de mediação, mas, também, utilizadas nas audiências de conciliação, fundamentada em Brasil (2016) e Takahashi (2019).

\subsection{Recontextualização (ou paráfrase)}

Nesta técnica, em conformidade com Takahashi et al. (2019), o mediador pode fazer um resumo do que foi dito de forma fiel, de forma atenuadora e buscando a confirmação das partes pelo seu entendimento ou utilizar a reformulação com uma conotação positiva dos fatos, ou ainda, recontextualizar o problema apontado em um novo contexto, isto é, "consiste em uma técnica segundo a qual o mediador estimula as partes a perceberem determinado contexto fático por outra perspectiva" (BRASIL, 2016, p. 234).

Nos estudos linguísticos, a paráfrase, segundo (Hilgert, 2015) tem um caráter retrospectivo, pode acontecer por meio da repetição ou correção do texto, implicando um deslocamento do sentido e contribuindo para a continuidade textual, ou seja, há uma relação de sentido entre a fala-origem ${ }^{7}$ e a fala-reformulada. Segundo Castilho (2014), o falante escolhe um ponto de vista para realizar a representação do que foi dito, assim, podemos parafrasear a fala de alguém e chamar atenção para aspectos que precisam ser destacados, em outras palavras, denota a função de reforço - no caso da mediação, reforçar os aspectos positivos e mostrar atenção ao falante.

Quadro 1 - Dicas para recontextualização (paráfrase)

\begin{tabular}{l|l}
\multicolumn{1}{c|}{ ESTRATÉGIAS/EXEMPLOS DE USO } & \multicolumn{2}{|c}{ OBSERVAÇÕES } \\
\hline Não sei se compreendi adequadamente (perfeitamente), "Afasta, por antecipação, a \\
entretanto, acredito que o(a) senhor(a) quis dizer (que)... & $\begin{array}{l}\text { indisposição do ouvinte com } \\
\text { respeito a a enunciado } \\
\text { subsequente" (ROSA, 1992). }\end{array}$ \\
\hline Não sei se entendi bem (corretamente), mas, acho (creio) & "Afasta, por antecipação, a
\end{tabular}

\footnotetext{
${ }^{7}$ Em Hilgert (2015) são apresentados os termos texto-origem e texto-reformulado, por uma questão de adequação a este trabalho, utilizamos os termos fala-origem e fala-reformulada, por se tratar de um contexto de oralidade.
} 
que você quis dizer (que)...

indisposição do ouvinte com respeito ao enunciado subsequente" (ROSA, 1992).

Como você (senhor(a)) falou, houve uma situação Preservação do mediador por complicada em que..., entretanto, os senhores estão aqui hoje com intuito de tentarem dialogar e ver uma a não se responsabilizar pela possibilidade de boa solução para ambos, entendi corretamente?

Quer dizer (que) os senhores passaram por um momento complicado, o que gerou um desconforto em razão (de)..., mas estão aqui com o interesse em tentar resolver essa questão, certo?

Busca a confirmação dos fatos pelas partes e não impõe a interpretação $\quad \operatorname{do}(a)$

Em outras palavras, vocês me disseram que .... é isso mediador(a). mesmo?

Como disseram há pouco, houve um desentendimento em consequência de... entendi corretamente?

Introduz a recontextualização.

Bus

Busca a confirmação dos fatos pelas partes e não impõe a interpretação $\operatorname{do}(\mathrm{a})$ mediador(a).

Como vocês falaram... Introduz a recontextualização.

Acredito que está sendo claro em dizer que (quer/ preferi)... porque tem a necessidade de... correto?

Poderia ser usado na sessão individual para identificar as necessidades reais de uma das partes.

\begin{tabular}{l|l}
\hline Pelo que percebo... é isso mesmo? & Busca a confirmação das partes. \\
\hline O fato que se requer é... em virtude do aborrecimento & $\begin{array}{l}\text { Coloca em foco o pedido para } \\
\text { iniciar a recontextualização. }\end{array}$ \\
ocorrido após..., estou certo? & $\begin{array}{l}\text { Estruturas atenuadoras e } \\
\text { introdutoras de paráfrases. }\end{array}$ \\
\hline Tenho a impressão de que você quis dizer...; Parece que \\
você gostaria... O que me parece é... & $\begin{array}{l}\text { Estruturas introdutoras de } \\
\text { paráfrases. }\end{array}$ \\
\hline Isto é, ou seja, quer dizer, ou melhor, em outras palavras, \\
em síntese, em resumo.
\end{tabular}

Fonte: adaptação de Brasil (2006), Campato Jr. (2015), Castilho (2014), Dicionário de Sinônimos Online (2019), Kerbrat-Orecchioni (2006), Koch (2011, 2015, 2016a, 2016b 2017), Marcuschi (1986), Urbano (2015). 


\subsection{Escuta ativa - audição de propostas implícitas}

Conforme Brasil (2016), o mediador deve estar atento para o desejo (soluções) implícito na fala das partes, ainda que elas também não percebam que possuem uma possível solução. Vale ressaltar, ainda, segundo Takahashi [et al.] (2019, p. 78), que "cabe sinalizar, inclusive por linguagem corporal, que se está prestando atenção naquilo que está sendo dito. Tomar notas pode ajudar, desde que o ato de anotar não represente por si só um desvio de atenção".

Nessa técnica, espera-se que o mediador tenha uma postura neutra e atenta. Quanto às partes, é preciso perceber suas intenções, ainda que implícitas, e também, mostrar respeito e atenção aos relatos contados. Na Análise da Conversação, denominamos monitoramento do falante quando o interlocutor está atento à interação, mas não julga valores, não concorda necessariamente com o que é dito, apenas demonstra compreensão e atenção, como evidenciado por Urbano (2015) como marcadores discursivos basicamente interacionas, ou seja, não constituem conteúdo proposicional ou sintático. Nesse caso, vale ressaltar alguns marcadores discursivos emitidos por meio de sons, palavras e gestos, tais como: ah, ahn, hem?, sabe?, né, e outros.

Ao relacionar essa técnica aos estudos linguísticos, podemos considerar dois pontos relevantes: o primeiro é o monitoramento do falante, que na perspectiva da Análise da Conversação é tido como um aspecto importante para organização do fluxo das mensagens. Em consonância com Galembeck (2016), consideramos importante a existência de uma sistemática para organizar essa transição entre falante e ouvinte, além disso, é uma maneira de quem está no papel de falante se sentir ouvido, perceber a atenção do seu ouvinte.

O segundo aspecto linguístico que pode contribuir para a escuta ativa/audição de propostas implícitas é análise pragmática de uso da língua. Nesse caso, é importante ressaltar alguns pontos sobre as inferências, pressupostos e subentendidos ocorridos nas interações orais. Para Fiorin (2002, p.168), "certos enunciados têm a propriedade de implicar outros", assim, podemos considerar que os estudos das ideias implícitas podem contribuir para identificar as intenções do interlocutor.

Em continuidade, com base na teoria da Grice (1982), vale ressaltar a noção das implicaturas que são abordadas em Fiorin (2002), como inferências que podemos extrair dos enunciados, ou seja, deduções do que o falante não falou explicitamente.

Concomitante a isso, cabe salientar, também, nas palavras de Fiorin (2002, p. 178): 
A lógica da conversação é diferente da lógica formal. Nesta, quando se diz que alguém tem quatro apartamentos, pressupõe-se que ele tem três, porque três está contido em quatro. Na conversação, isso não ocorre, porque se se diz que tem quatro apartamentos, está-se dizendo que são exatamente quatro e não três.

Ainda nessa perspectiva, com relação à lógica conversacional de Grice (1982) temos dois tipos de implicaturas, as convencionais - que ocorrem por meio da análise de expressões linguísticas; e as conversacionais - que vão depender do contexto de uso e de conhecimentos prévios dos falantes para compreensão total da mensagem, seja por elementos implícitos ou explícitos. Temos como exemplo:

Implicatura convencional: Ele fez faculdade, mas não sabe escrever.

Desencadeada pela conjunção mas: quem fez faculdade deveria escrever bem, logo, estudou mais.

Implicatura conversacional: A defesa da tese de Mário correu bem, não o reprovaram.

Há a implicatura de que a tese não estava boa, já que é de conhecimento a mínima possibilidade de uma tese ser reprovada, dessa forma, se Mário corria o risco de ter a tese reprovada é porque esta não estava bem escrita, não era uma boa tese - ideia implícita com base no contexto (FIORIN, 2002, p. 176).

No que se refere aos elementos implícitos e explícitos, podemos destacar, ainda, os pressupostos e subentendidos. O primeiro é a informação que não é claramente dita e veiculada pelo enunciado; já os subentendidos são veiculados por contextos particulares de uso. As informações implícitas são identificadas pelo contexto, todavia, há possibilidades de questionamentos dos subentendidos, é o famoso "eu não disse isso" “- mas quis dizer”, é a “sugestão (insinuação e alusão)" de algo, o dizer sem dizer. Fiorin (2002, p. 183-4) apresentanos os principais marcadores linguísticos da pressuposição, expostos a seguir no quadro dois.

Quadro 2 - Dicas para Escuta ativa - audição de propostas implícitas

MARCADORES LINGUÍSTICOS DE

OBSERVAÇÕES

PRESSUPOSIÇÃO

\begin{tabular}{|c|c|}
\hline $\begin{array}{l}\text { Adjetivos } \\
\text { A única coisa que me preocupa no plano é que os } \\
\text { economistas estão gostando dele. (Jô Soares) }\end{array}$ & $\begin{array}{l}\text { O adjetivo única pressupõe que o } \\
\text { plano não traz nenhuma outra } \\
\text { preocupação. }\end{array}$ \\
\hline $\begin{array}{l}\text { Verbos que indicam permanência ou } \\
\text { estado (tornar-se, transformar-se, conv }\end{array}$ & $\begin{array}{l}\text { Pressupostos pelo verbo continuar: a } \\
\text { impressa é livre, a impressa colabora }\end{array}$ \\
\hline
\end{tabular}


vir, a ser, passar, deixar de, começar a, principiar a, ganhar, perder, permanecer, continuar).

A impressa continuará livre, mas é preciso que continue colaborando com as autoridades. (Gal. Justino Alves Bastos)

Verbos que revelam ponto de vista (pretender, alegar, supor, presumir, imaginar).

Ele pretende que tudo se passou da maneira como conta.

Certos advérbios

O país está muito mal, e não quero mais fazer o

As Orações Adjetivas

Não adianta investigar os parlamentares se a elite empresarial que financia a corrupção fica assistindo às sessões da CPI pela televisão. (Senador José Paulo Bisol, ao defender a tese de que a corrupção é como pederastia, não tem ativo ou passivo). papel de bobo da corte. (Xuxa)

com as autoridades (acréscimo nosso: mesmo sendo livre a imprensa precisa colaborar com as autoridades; não pode fazer apenas o que quer).

Pressupostos pelo verbo pretender: o falante não aceita como verdade o que alguém apresenta como tal, (acréscimo nosso: aceita como verdade o que ele mesmo conta).

Implica na ideia de que antes o produtor do texto fazia papel de bobo da corte.

A oração que financia a corrupção é restritiva e pressupõe que não é toda a elite empresarial que financia a corrupção, apenas parte dela.

Se fosse uma oração adjetiva explicativa iria generalizar a ideia de que toda elite empresarial financia a corrupção.

Maria gosta de ser mediadora.

Pressuposto: Maria é mediadora.

Subentendido: $\mathrm{O}$ trabalho de mediador é bem remunerado, é um trabalho tranquilo.

O subentendido está na condição de que para alguém gostar do trabalho, deve-se ter um bom salário, bom convívio com os colegas ou com as pessoas para quem presta-se algum serviço.

Pressuposto: Não está tudo bem.

Faça como achar melhor, mas eu não vou ficar fingindo que está tudo bem.
Subentendido: Alguém está fingindo 


\begin{tabular}{|c|c|}
\hline & $\begin{array}{l}\text { que está tudo bem. } \\
\text { O uso do pronome "eu" indica que } \\
\text { fará diferente de alguém, ou seja, não } \\
\text { vai fingir que está tudo bem. }\end{array}$ \\
\hline OUTRAS ESTRATÉGIAS/EXEMPLOS DE USO & OBSERVAÇÕES \\
\hline Ah; Uhn & Sinal de escuta. \\
\hline Huu::m & $\begin{array}{l}\text { Sinal de escuta. } \\
\text { Evite alongamentos de vogais (ou } \\
\text { interjeições), o interlocutor pode } \\
\text { entender que está esboçando algum } \\
\text { tipo de valor ao que é dito. }\end{array}$ \\
\hline Estou te acompanhando. & Sinal de escuta. \\
\hline $\begin{array}{l}\text { Desculpe-me, você (senhor) poderia repetir (falar } \\
\text { um pouco mais sobre isto...). }\end{array}$ & $\begin{array}{l}\text { Uso do Futuro do Pretérito, verbos } \\
\text { conjugados como: poderia, gostaria, } \\
\text { diria, pensaria... podem contribuir } \\
\text { para atenuação da locução. }\end{array}$ \\
\hline Por favor, se possível, poderia me falar mais sobre... & $\begin{array}{l}\text { Evite dizer que não entendeu; } \\
\text { também usado para explorar mais a } \\
\text { narração de fatos. }\end{array}$ \\
\hline $\begin{array}{l}\text { Por favor, poderia dizer de forma mais específica o } \\
\text { que espera desta sessão? }\end{array}$ & $\begin{array}{l}\text { Modalizador para solicitar mais } \\
\text { informação. Questão aberta para } \\
\text { identificar interesses específicos. }\end{array}$ \\
\hline ELEMENTOS PARALINGUÍSTICOS & $\begin{array}{l}\text { Conforme estudos da linguagem } \\
\text { gestual e sinais paralinguísticos }\end{array}$ \\
\hline Olhar & $\begin{array}{l}\text { Manter o olhar direcionado para } \\
\text { quem fala, mostrando atenção ao } \\
\text { interlocutor. }\end{array}$ \\
\hline Braço Cruzado & $\begin{array}{l}\text { Indica uma postura de negação, } \\
\text { assim, precisa evitar para demonstrar } \\
\text { interesse no ouvinte. } \\
\text { Com relação à parte, caso esteja com } \\
\text { os braços nessa posição, pode ser uma } \\
\text { demonstração de rejeição. }\end{array}$ \\
\hline
\end{tabular}




\begin{tabular}{|c|c|}
\hline Postura & $\begin{array}{l}\text { Deve estar sempre alinhada para } \\
\text { passar confiança e demonstrar } \\
\text { interesse no assunto. }\end{array}$ \\
\hline Bater caneta ou dedos na mesa & $\begin{array}{l}\text { Pode passar a ideia de impaciência } \\
\text { com o ouvinte, por isso é melhor } \\
\text { evitar. }\end{array}$ \\
\hline O quê? Quem? Para quê? Para quem? & $\begin{array}{l}\text { Perguntas para complementos verbais } \\
\text { e/ou nominais. Ex. Estou triste (com o } \\
\text { quê?); estou cansado (de quê?), } \\
\text { incentivar o ouvinte a especificar } \\
\text { melhor seus desejos e/ou intenções. }\end{array}$ \\
\hline Ele poderia ter dito (feito), pelo menos... & $\begin{array}{l}\text { Dependendo do complemento da } \\
\text { frase, pode-se usar os sentimentos } \\
\text { elencados, no quadro 19, para } \\
\text { entender o sentimento e a necessidade } \\
\text { implícita. }\end{array}$ \\
\hline Ela nem sequer se desculpou. & $\begin{array}{l}\text { Interesse implícito de realizar pedido } \\
\text { de desculpas; pode ser explorada no } \\
\text { afago. }\end{array}$ \\
\hline Sinto muito por... & $\begin{array}{l}\text { Interesse implícito de realizar pedido } \\
\text { de desculpas; pode ser explorada no } \\
\text { afago. }\end{array}$ \\
\hline Eu me sinto muito mal por ... & $\begin{array}{l}\text { Interesse implícito de realizar pedido } \\
\text { de desculpas ou mostrar solidariedade } \\
\text { (dependendo do contexto); pode ser } \\
\text { explorada no afago. }\end{array}$ \\
\hline
\end{tabular}

Fonte: adaptação de Brasil (2006), Campato Jr. (2015), Castilho (2014), Dicionário de Sinônimos Online (2019), Fiorin (2002), Kerbrat-Orecchioni (2006), Koch (2011, 2015, 2016a, 2016b 2017), Marcuschi (1986), Urbano (2015), Weil (2011).

\subsection{Afago (ou reforço positivo)}


Conforme Brasil (2016), ao perceber um comportamento ou afirmação positiva de uma das partes ou de seus respectivos advogados, o mediador deve evidenciar esse comportamento e estimular à percepção da outra parte para tal conduta, porém sem explicitar ou deixar a parte constrangida por afirmar que algo foi dito implicitamente.

Nessa direção, Barbosa (1996, p. 6) evidencia que "os falantes, de modo geral, têm o desejo de serem admirados pelos seus interlocutores, no entanto, quando são receptores de elogios, seguem a regra geral da modéstia em suas respostas e tendem a discordar e evitar os elogios", por isso a importância de reconhecer comportamentos positivos e reforçá-los, no entanto, de maneira contida (atenuada) e polida.

Quadro 3 - Dicas para Afago (ou reforço positivo)

ESTRATÉGIAS/EXEMPLOS DE USO

Eu penso; creio; acredito; tenho a impressão que...; possivelmente; provavelmente.

Parece-me que esse raciocínio poderia ser o início de um
acordo, isto é, um ponto muito positivo e produtivo para a
mediação.

Em acrescimento a esta atitude positiva, gostaria de dizer que este seria um caminho para um possível acordo.

Parabéns pela sua postura, e reforçando o que você disse...
Atenuador;

sublinhada seria o reforço positivo.

Estrutura sublinhada seria o reforço positivo.

Afago explícito e

oportunidade de recontextualização.

\begin{tabular}{l|l} 
& $\begin{array}{l}\text { oportunidade } \\
\text { recontextualização. }\end{array}$ \\
\hline Acredito que este é o caminho, muito bem! & Afago implícito, moderado. \\
\hline $\begin{array}{l}\text { Acredito que estamos no caminho certo, pensando desta } \\
\text { forma, parabéns por estar disposto a mudar. }\end{array}$ & $\begin{array}{l}\text { Afago implícito, moderado. } \\
\text { Muito bem, acredito que conseguiram refletir sobre a melhor } \\
\text { decisão para ambos, pensando no bem-estar de todos, assim } \\
\text { todos ganham e saem satisfeitos daqui. }\end{array}$ \\
\hline Parabéns; Salientou bem; ótimas considerações sobre... & $\begin{array}{l}\text { Estruturas para cumprimentar/ } \\
\text { parabenizar pelas atitudes } \\
\text { positivas. }\end{array}$ \\
\hline Infelizmente, posturas como estas estão em falta, vocês estão & $\begin{array}{l}\text { Afago explícito. } \\
\end{array}$
\end{tabular}


de parabéns por agirem assim.

Ótimo, ficamos felizes pela disponibilidade de vocês em dialogar e buscar mudanças que possam contribuir para o futuro.

O uso do pronome "nós" causa aproximação dos falantes com as partes.

Que bom que pensam (agem) dessa forma, é um ganho para Afago moderado. todos.

Fonte: adaptação de Brasil (2006), Campato Jr. (2015), Castilho (2014), Dicionário de Sinônimos Online (2019), Kerbrat-Orecchioni (2006), Koch (2011, 2015, 2016a, 2016b 2017), Marcuschi (1986), Urbano (2015).

\subsection{Silêncio}

Segundo Brasil (2016), o mediador deve considerar a existência do silêncio, respeitálo e aproveitá-lo de forma positiva. Além disso, na perspectiva linguística, o silêncio, as pausas e as hesitações na fala, conforme Marcuschi (1986), são organizadores locais, ou seja, é um momento marcado pelo planejamento do falante e pode ser também a transição de falantes. Além disso, o silêncio pode ter valor significativo, com a função de discurso, por exemplo, uma resposta proposital por meio do silêncio, um tipo de concordância ou não.

Quadro 4 - Dicas para técnica do Silêncio

\begin{tabular}{l|l}
\multicolumn{1}{c|}{ ESTRATÉGIAS/EXEMPLOS } & \multicolumn{1}{c}{ OBSERVAÇÕES } \\
\hline Silêncio (parte quando ouvinte) & $\begin{array}{l}\text { Despreferência ou desaprovação do que foi dito pelo(a) } \\
\text { mediador(a). Assim, seria a oportunidade para "corrigir" } \\
\text { o que foi dito com uma paráfrase ou pedido de desculpas. }\end{array}$ \\
\hline Silêncio (parte quando ouvinte) & $\begin{array}{l}\text { Desconhecimento ou falta de interesse em responder a } \\
\text { uma pergunta realizada pelo(a) mediador(a) ou pela outra } \\
\text { parte. }\end{array}$ \\
\hline Silêncio (mediador) & $\begin{array}{l}\text { Como aponta os manuais, pode ser um tempo para } \\
\text { respeitar algum momento de emoção ou reflexão de uma } \\
\text { das partes, ou também, poderia ser uma forma de mostrar } \\
\text { que os ânimos precisam ser acalmados, uma reprovação } \\
\text { do comportamento das partes, por exemplo, casos em que }\end{array}$
\end{tabular}


um não deixa o outro falar ou algum desrespeito verbalizado.

Fonte: adaptação de Brasil (2006), Kerbrat-Orecchioni (2006), Koch (2011, 2015, 2016a, 2016b 2017), Marcuschi (1986).

\subsection{Sessões privadas ou individuais}

Sempre que necessário, o mediador deve realizar as sessões privadas, considerando o tempo e a quantidade de sessões privadas por igual para as partes. Nessa técnica, é muito importante o cuidado com a imparcialidade, em razão das partes acreditarem que o mediador esteja “do seu lado". Em consonância com Brasil (2016):

O mediador deve avisar que, eventualmente, fará sessões privadas ainda na sua declaração de abertura para que as partes não se surpreendam com a prática. Em regra, recomenda-se que o mediador inicie uma sessão privada com um resumo de conteúdo (questões e interesses) ou com uma validação de sentimentos (BRASIL, 2016, p. 237).

Com base no contexto da mediação, a relevância das sessões individuais se dá pela falta de comunicação e/ou por insultos, alteração do tom de voz -, que pode ocorrer por pelo menos uma das partes, isto é, ocorre uma tensão conversacional. Dessa maneira, Galembeck (2011) destaca o componente intersubjetivo nas relações interpessoais e explica que essa tensão ocorre pelo tipo de contato e envolvimento que os interlocutores estabelecem, especialmente, a tensão coloquial afetiva, que decorre de causas/emoções e interfere na fala dos participantes da interação.

Quadro 5 - Dicas para usar nas sessões individuais

ESTRATÉGIAS/EXEMPLOS DE USO OBSERVAÇÕES

PARA CHAMAR AS PARTES PARA A SESSÃO INDIVIDUAL

\begin{tabular}{l|l}
\hline Senhores(as), como havia mencionado na declaração de & $\begin{array}{l}\text { O uso da estrutura } \\
\text { abertura, irei ouvi-los separadamente. }\end{array}$ \\
"Senhores(as)" pode ser uma \\
forma de interromper uma \\
discussão e chamar a atenção das \\
partes para si.
\end{tabular}


separadamente, pois acredito que poderá facilitar e| chamar a atenção das partes. contribuir para um possível acordo.

Deixe-me, apenas, fazer uma colocação, faremos, agora, as sessões individuais...

Retomada de turno $^{8}$ (direito a fala) atenuada pela palavra "apenas".

Parece-me que temos um problema de comunicação, Para iniciar a sessão de forma desta forma, acredito que será mais produtivo iniciarmos atenuada.

com a sessão privada e depois conversaremos conjuntamente.

\begin{tabular}{l|l}
\hline $\begin{array}{l}\text { Deixe-me, apenas, fazer uma colocação, faremos, agora, } \\
\text { as sessões individuais... }\end{array}$ & $\begin{array}{l}\text { Retomada de turno, mais } \\
\text { atenuada pela palavra "apenas". }\end{array}$ \\
\hline Por favor, deixe-me falar... & Retomada de turno. \\
\hline $\begin{array}{l}\text { Espero que não me entendam mal, mas acredito que a } \\
\text { sessão individual será melhor neste momento. }\end{array}$ & $\begin{array}{l}\text { Desarmador e atenuador para } \\
\text { chamar as partes para a sessão } \\
\text { individual. }\end{array}$ \\
\hline Como já frisei anteriormente, faremos as sessões & $\begin{array}{l}\text { Retoma a ideia combinada no } \\
\text { início da sessão. }\end{array}$ \\
individuais e depois voltaremos todos para a sala. &
\end{tabular}
DURANTE A SESSÃO INDIVIDUAL

Bom, senhor gostaria de reforçar o princípio Enfatiza o princípio da da confidencialidade na sessão privada, de tudo o que o confidencialidade.

senhor falar, só será repassado para a (outra parte) o que nos for autorizado.

Bom, senhor _ gostaria de frisar sobre o

princípio da confidencialidade na sessão privada, então confidencialidade.

fique tranquilo com relação a tudo que disser aqui, porque só serão faladas a (fulano) o que o senhor nos autorizar.

Quer dizer isto na sessão conjunta?

Transfere autonomia para a parte e oportunidade de expressão com relação à outra pessoa.

Você gostaria de dizer isso para (fulano) ou posso falar para (ele) na sessão individual que teremos a seguir?

Transfere autonomia para a parte e oportunidade de expressão com

\footnotetext{
${ }^{8}$ Turno, de forma geral, é o direito de fala de cada participante da interação, o turno é de quem está falando.
} 


\begin{tabular}{|c|c|}
\hline & relação à outra pessoa. \\
\hline $\begin{array}{l}\text { Você me autoriza a dizer isto para (fulano) na sessão } \\
\text { individual que terei com ele? }\end{array}$ & $\begin{array}{l}\text { Pedido de autorização para } \\
\text { repasse de informações; esta } \\
\text { atitude pode, também, reforçar o } \\
\text { rapport. }\end{array}$ \\
\hline $\begin{array}{l}\text { Por gentileza, pode me descrever de forma mais detalhada } \\
\text { (ou específica) o que o(a) senhor(a) está propondo (ou } \\
\text { quer). }\end{array}$ & $\begin{array}{l}\text { Pode gerar oportunidade para o } \\
\text { teste de realidade ou inversão de } \\
\text { papéis. }\end{array}$ \\
\hline $\begin{array}{l}\text { Poderia (gostaria) de me contar algo que você fez e } \\
\text { gostaria de mudar ou reparar? }\end{array}$ & $\begin{array}{l}\text { Cria oportunidade de mudança } \\
\text { de comportamento. }\end{array}$ \\
\hline Eu poderia dizer para (fulano) que... & $\begin{array}{l}\text { Pedido de autorização para } \\
\text { repasse de informações; esta } \\
\text { atitude pode, também, reforçar o } \\
\text { rapport. }\end{array}$ \\
\hline
\end{tabular}

Fonte: adaptação de Brasil (2006), Campato Jr. (2015), Castilho (2014), Dicionário de Sinônimos Online (2019), Kerbrat-Orecchioni (2006), Koch (2011, 2015, 2016a, 2016b 2017), Marcuschi (1986), Urbano (2015).

\subsection{Inversão de papéis}

Em Brasil (2016), a inversão de papéis tem como objetivo fazer com que uma parte considere o ponto de vista da outra parte, bem como, despertar a empatia entre elas.

Recomenda-se enfaticamente que esta técnica seja usada prioritariamente em sessões privadas e que ao se aplicar a técnica o mediador indique: i) que se trata de uma técnica de mediação e ii) que esta técnica também será utilizada com a outra parte. Assim, o mediador terá mais facilidade para manter sua imparcialidade e, sobretudo, as partes também o verão como um autocompositor imparcial (BRASIL, 2016, p. 237).

Diante da concepção de língua como instrumento de comunicação, não podemos desconsiderar o valor interpessoal e seu efeito significativo na interação. Em concordância com Slobin (1980) a língua influencia os modos pelos quais armazenamos uma velha informação e adquirimos uma nova, portanto, é possível que a parte, no caso da mediação, estimulada a pensar de uma forma distinta de antes, tendo pontos de vista, palavras positivas e 
bons argumentos para uma mudança de postura, a inversão de papéis poderá modificar tanto o modo de agir quanto o modo de falar e pensar.

Quadro 6 - Dicas para inversão de papéis

\begin{tabular}{|c|c|}
\hline ESTRATÉGIAS/EXEMPLOS DE USO & OBSERVAÇÕES \\
\hline $\begin{array}{l}\text { Senhor(a), existe uma técnica na mediação chamada } \\
\text { inversão de papéis que vou aplicar agora com o } \\
\text { senhor(a). }\end{array}$ & $\begin{array}{l}\text { Aviso sobre a aplicação da } \\
\text { técnica. }\end{array}$ \\
\hline $\begin{array}{l}\text { João, pelo que percebo o senhor parece descontente } \\
\text { com toda situação, gostaria de aplicar agora uma } \\
\text { técnica da mediação, chamada inversão de papéis, que } \\
\text { talvez possa te fazer ver a situação por outra } \\
\text { perspectiva. }\end{array}$ & $\begin{array}{l}\text { Preâmbulo para contextualizar a } \\
\text { aplicação da técnica. } \\
\text { Aviso sobre a aplicação da } \\
\text { técnica. }\end{array}$ \\
\hline $\begin{array}{l}\text { Fulano(a), um dos objetivos da mediação é tentar nos } \\
\text { fazer ver cada acontecimento sob várias perspectivas } \\
\text { (pontos de vista), por isso vou aplicar uma técnica } \\
\text { chamada inversão de papéis. }\end{array}$ & $\begin{array}{l}\text { O uso do pronome "nós" cria } \\
\text { aproximação e mostra para a parte } \\
\text { que o(a) mediador(a) também pode } \\
\text { mudar de comportamento e } \\
\text { posicionamento. } \\
\text { Aviso sobre a aplicação da } \\
\text { técnica. }\end{array}$ \\
\hline $\begin{array}{l}\text { Se fosse você no lugar dele, o que faria? Qual é a sua } \\
\text { sugestão? }\end{array}$ & $\begin{array}{l}\text { O uso do pronome "você" neste } \\
\text { caso pode atrapalhar na separação } \\
\text { da pessoa do problema. }\end{array}$ \\
\hline Vamos tentar nos colocar no lugar dele (a)? & $\begin{array}{l}\text { O uso do pronome "dele", neste } \\
\text { caso, pode atrapalhar na separação } \\
\text { da pessoa do problema. }\end{array}$ \\
\hline $\begin{array}{l}\text { E se fosse com você nesse contexto... como gostaria de } \\
\text { ser tratado? Como teria agido? }\end{array}$ & $\begin{array}{l}\text { Exemplos }{ }^{9} \text { e ilustração de fatos e } \\
\text { circunstâncias hipotéticas são } \\
\text { argumentos que podem contribuir } \\
\text { com a inversão de papéis. }\end{array}$ \\
\hline Como & Colocando-se na situação do outro, \\
\hline
\end{tabular}

\footnotetext{
${ }^{9}$ Segundo Costa (2017), o exemplo e a ilustração são tipos de argumento que fundam a estrutura do real, ou seja, enfoca situações e resultados de fatos reais. Estes tipos de argumentos podem causar algum efeito na memória afetiva das pessoas e facilitar o trabalho de inversão de papéis.
} 


\begin{tabular}{|c|c|}
\hline & sem foc \\
\hline $\operatorname{Ima}$ & $\begin{array}{l}\text { Colocando-se na situação do outro, } \\
\text { sem focar na pessoa. }\end{array}$ \\
\hline $\begin{array}{l}\text { É importante lembrar que cada um de nós } \\
\text { desempenhamos papéis diferentes e em contextos } \\
\text { diferentes, assim, o que acha de se colocar na posição } \\
\text { diferente da sua. }\end{array}$ & $\begin{array}{l}\text { O uso da primeira pessoa do plural } \\
\text { "nós" para criar aproximação, } \\
\text { rapport com a parte. }\end{array}$ \\
\hline $\begin{array}{l}\text { Independente das pessoas envolvidas, é comum } \\
\text { repensarmos nossas atitudes e nos colocarmos em outras } \\
\text { situações ou funções, o que acha que você faria nesta } \\
\text { circunstância? }\end{array}$ & $\begin{array}{l}\text { O uso da primeira pessoa do plural } \\
\text { "nós" para criar aproximação, } \\
\text { rapport com a parte; tentativa de } \\
\text { separar a pessoa do problema. }\end{array}$ \\
\hline $\begin{array}{l}\text { Como você vê essa questão de outro modo, por outro } \\
\text { ponto de vista? }\end{array}$ & $\begin{array}{l}\text { Colocando-se na situação do outro, } \\
\text { sem focar na pessoa. }\end{array}$ \\
\hline
\end{tabular}

Fonte: adaptação de Brasil (2006), Campato Jr. (2015), Castilho (2014), Dicionário de Sinônimos Online (2019), Kerbrat-Orecchioni (2006), Koch (2011, 2015, 2016a, 2016b 2017), Marcuschi (1986), Urbano (2015).

\subsection{Geração de opções/perguntas orientadas a geração de opções}

De acordo com Brasil (2016), o mediador deve estimular as partes, por meio de perguntas, a pensarem em soluções, para que reflitam e criem novas perspectivas de resoluções de conflitos, compreendendo que as melhores soluções devem vir delas mesmas.

É importante também, conforme previsto em Brasil (2016), que o mediador escute todas as soluções, faça com que as partes pensem umas nas outras na hora das propostas, incentive a criatividade das partes para fazerem o que realmente importa para elas e não se preocuparem com ideias preestabelecidas.

O contexto da geração de opções pode ser considerado um dos momentos de empoderamento das partes na mediação, visto que é um tempo que elas possuem para pensar nas suas possibilidades e sugerir opções para resolver o conflito. Assim, essa técnica pode ser relacionada à Teoria da Polidez, que indica a preocupação do falante com sua autoimagem. Dessa forma, ele, possivelmente, não fará sugestões absurdas, caso não queira ser malvisto na audiência, tal como pode ser um momento para despertar a empatia e pensar nos dois lados para gerar opções. 
Por outro lado, a geração de opções também é um momento de negociação. Diante disso, a pessoa envolvida no conflito pode optar por recorrer a elementos de argumentação, como a exposição de fatos e a causalidade dos fatos, julgamentos sobre a outra parte para tentar vantagens, ou até mesmo para se mostrar uma pessoa colaborativa. Nessa situação, recorrer às técnicas de "organização de questões e interesses" e "inversão de papéis" seria uma opção para o facilitador da sessão.

Quadro 7 - Dicas para geração de opções

\begin{tabular}{|c|c|}
\hline GIAS/EXEM & OBSERVAÇĈ́ \\
\hline Que; & $\begin{array}{l}\text { Estruturas que possibilitam as perguntas } \\
\text { abertas e incentivam narrativas mais } \\
\text { completas dos fatos e interesses. }\end{array}$ \\
\hline Com & $\begin{array}{l}\text { Autonomia das partes pela } 2^{\mathrm{a}} \text { pessoa } \\
\text { implícita na fala (tu, você). }\end{array}$ \\
\hline $\begin{array}{l}\text { No seu ponto de vista, qual seria a melhor } \\
\text { maneira de resolvermos isso? }\end{array}$ & \\
\hline $\begin{array}{l}\text { Que outra saída o(a) senhor(a) vê para resolver } \\
\text { essa situação? }\end{array}$ & $\begin{array}{l}\text { Questão aberta para explorar mais } \\
\text { informações e tentar deixar os fatos } \\
\text { específicos. }\end{array}$ \\
\hline O que 1 & . C IIC \\
\hline $\begin{array}{l}\text { Qual atitude ele(a) poderia ter para o senhor se } \\
\text { sentir melhor? }\end{array}$ & $\begin{array}{l}\text { Questão aberta para identificar o que se } \\
\text { espera da outra parte. }\end{array}$ \\
\hline $\begin{array}{l}\text { Qual atitude ele(a) poderia ter para o senhor se } \\
\text { sentir mais satisfeito? }\end{array}$ & $\begin{array}{l}\text { Questão aberta para identificar o que se } \\
\text { espera da outra parte. }\end{array}$ \\
\hline $\begin{array}{l}\text { Qual atitude o senhor poderia ter para que ela se } \\
\text { sentisse melhor e talvez mudasse de pensamento? }\end{array}$ & $\begin{array}{l}\text { Questão aberta para identificar a } \\
\text { possibilidade de mudança de } \\
\text { comportamento (e quais comportamentos } \\
\text { mudariam). }\end{array}$ \\
\hline Na su & Emp \\
\hline O que de solução vocês possuem para hoje? & Empoderamento das partes. \\
\hline $\begin{array}{l}\text { Nesse meio tempo, o que a senhora pensou que } \\
\text { poderia ser feito? }\end{array}$ & $\begin{array}{l}\text { Poderia ser utilizado numa segunda } \\
\text { sessão individual ou conjunta. }\end{array}$ \\
\hline
\end{tabular}


Talvez fosse melhor...

Atenuador, caráter sugestivo, poderia ser mais utilizado na conciliação.

Acredita que se sentirá melhor caso mudasse de postura (ideia)?

Identificação de possibilidade de mudança de comportamento (e quais

Se sim, o que poderia mudar? Como se sentiria?

comportamentos mudariam).

Do seu ponto de vista, qual seria a solução para

Empoderamento das partes.

esta situação?

Se considerarmos...

Atenuador, caráter sugestivo, poderia ser mais utilizado na conciliação.

O que deseja alcançar daqui pra frente?

Empoderamento das partes.

Como deseja conduzir sua vida diante dessa

Pergunta aberta e incentivo à narrativa. situação?

$\mathrm{O}$ que você pode fazer para transformar as experiências negativas em aprendizado?

Empoderamento das partes; sugestão de mudança de postura; enfoque prospectivo.

E se você descobrisse que existe outro modo de perceber essa situação, você adotaria uma nova postura?

Se sim, qual?

$\mathrm{O}$ que você tem feito ou gostaria de fazer, na prática, para alcançar o seu objetivo?

Sugestão (implícita) de mudança de postura.

$\mathrm{O}$ que você gostaria que acontecesse até o final desta sessão?

O que te incomoda neste momento?

Identificação de interesses e/ou sentimentos para gerar opções.

Identificação de interesses e/ou sentimentos para gerar opções.

Identificação de interesses e/ou
sentimentos para gerar opções.

O que você poderia ou gostaria de mudar diante desta situação?

Identificação de interesses e/ou sentimentos para gerar opções.

O que te impede de fazer isto?

Fonte: adaptação de Brasil (2006), Campato Jr. (2015), Castilho (2014), Wilton Neto (2017?), Dicionário de Sinônimos Online (2019), Kerbrat-Orecchioni (2006), Koch (2011, 2015, 2016a, 2016b 2017), Marcuschi (1986), Urbano (2015). 


\subsection{Normalização}

Nesta estratégia, temos que ter a atenção voltada para a normalização do conflito e da presença das partes no ambiente jurídico, visto que muitas pessoas se sentem desconfortáveis e incomodadas por estarem em tal situação. Assim, "mostra-se recomendável que o mediador tenha um discurso voltado a normalizar o conflito e estimular as partes a perceber tal conflito como uma oportunidade de melhoria da relação entre elas e com terceiros" (BRASIL, 2016, p. 239).

Nesta técnica, temos explicitamente o olhar direcionado ao participante da mediação, que se preocupa com a autoimagem, que não vê sua presença no poder judiciário como algo positivo, então, possivelmente, a pessoa que se incomoda com esse fato, poderá ter uma de suas faces (imagens) atingidas.

Para melhor exemplificar, fundamentados nos postulados de Brown e Levinson (1987), podemos dizer que os falantes em uma interação possuem dois tipos de imagens, sua imagem interior, com valores, crenças e as subjetividades do seu próprio "eu"; e a imagem externa, que é a imagem que ele quer se mostrar para os outros, ou seja, a primeira refere-se ao "eu sou" e a segunda, é basicamente "aparento ser ou como quero que me vejam".

Durante a interação, conforme os autores citados, podemos ter algumas ameaças a essas imagens, na teoria que embasa este estudo, são atos que ameaçam a face, duas relacionadas ao emissor e outras duas relacionadas ao receptor. No primeiro caso, um exemplo seria uma promessa ou acordo proposto pelo falante, que colocaria em risco sua "honra (eu sou)", para o próprio emissor ferir sua imagem exterior (aparento ser) ele teria que fazer uma confissão, a auto degradação de seus comportamentos, como exposto em KerbratOrecchioni (2006).

Já com relação à face do receptor, em concordância com Kerbrat-Orecchioni (2006), podemos destacar como exemplo, as chamadas perguntas indiscretas ou inconvenientes, ordem, entre outros atos que expõe o ouvinte (imagem interior); e a crítica e/ou a reprovação podem ser exemplos que ferem o ego do ouvinte, que colocam em risco a imagem que quer mostrar socialmente. Por essas considerações, o modo de dizer e o dito precisam ser cuidados, considerando que pela necessidade de normalização do conflito, do contexto, já há algumas dessas imagens feridas e a possibilidade de embate pode ser maior. 
Quadro 8 - Dicas para normalização do conflito

\section{ESTRATÉGIAS/EXEMPLOS DE USO}

Normalmente, nos sentimos desconfortáveis neste ambiente de audiência, porém, é uma prática comum para encontrarmos uma solução positiva para ambos.

\section{OBSERVAÇÕES}

Nesta técnica, o uso do pronome "nós" é um grande contribuinte para a normalização, pois $\mathrm{o}(\mathrm{a})$ mediador(a) se coloca como cidadão comum e que ninguém está livre de passar pelo judiciário.

Visão do judiciário como uma boa oportunidade.

próprio, onde possam dialogar e tentar chegar a um acordo.

É comum nos dirigirmos ao judiciário para resolver nossas questões, é um momento importante para formalização de acordos.
Nesta técnica, o uso do pronome "nós" é um grande contribuinte para a normalização, pois $\mathrm{o}(\mathrm{a})$ mediador(a) se coloca como cidadão comum e que ninguém está livre de passar pelo judiciário.

Visão do judiciário como uma boa oportunidade e inovação.

Visão do judiciário como uma boa oportunidade. ambiente jurídico, mas ele foi criado para contribuir com nossas vidas, é uma forma de nos ajudar na solução de divergências.

Fonte: adaptação de Brasil (2006), Campato Jr. (2015), Castilho (2014), Dicionário de Sinônimos Online (2019), Kerbrat-Orecchioni (2006), Koch (2011, 2015, 2016a, 2016b 2017), Marcuschi (1986), Urbano (2015). 


\subsection{Organização de questões e interesses}

O mediador precisa conduzir a sessão de forma que as partes mantenham o foco na discussão que de fato importa para aquele momento, além disso, precisa captar os interesses reais implícitos e explícitos entre os mediandos.

Além do cuidado para atenuar sua fala, e não causar nenhum constrangimento às partes, o(a) mediador(a) ao tentar retomar o assunto, pode recorrer aos conhecimentos sobre Tópico Discursivo, conforme Jubran (2015) e Princípio da Cooperação desenvolvido por Grice (1982).

No que se refere ao tópico discursivo, de forma geral, podemos chamar de tema, o assunto da conversa, ou seja, aquilo sobre o que se fala; em uma interação podemos ter um ou mais tópico, dependendo dos interesses da conversação. Nesse sentido, o Princípio da Cooperação, de Grice (1982), tem como base quatro máximas que descrevem um comportamento colaborativo/cooperativo dos falantes.

A primeira é a máxima de quantidade, que tem como premissa básica de que o falante emita a informação "na quantidade" que foi requerida, que não fale a mais e nem a menos do que lhe foi solicitado, ou seja, controlar o fluxo de informação também seria uma forma de não fugir do assunto (tópico discursivo).

Uma segunda premissa seria de que o falante não deve falar aquilo que acredita ser mentira, regida pela máxima de qualidade. Nesse postulado, podemos destacar a ocorrência de ironia, uso de metáfora (um tipo de comparação) ou até mesmo os subentendidos, que mesmo não sendo uma resposta literal pode trazer o conteúdo implícito de forma verdadeira.

Por fim, temos outras duas máximas que é a máxima de relação, na qual o texto (a fala) dos interactantes precisa ser relevante, fazer sentido para tal conversa; e a máxima de modo, que indica a importância da clareza e objetividade na interação para uma conversa cooperativa. Há muito que se explorar dos postulados de Grice (1982), contudo, não é o objetivo desse trabalho discutir toda a teoria, visto que não adotamos uma visão ideal de comunicação e acreditamos que tais premissas podem nortear o(a) medidor(a) na observação do desenvolvimento do diálogo.

Quadro 9 - Dicas para organização de questões e interesses ESTRATÉGIAS/EXEMPLOS DE USO OBSERVAÇÕES

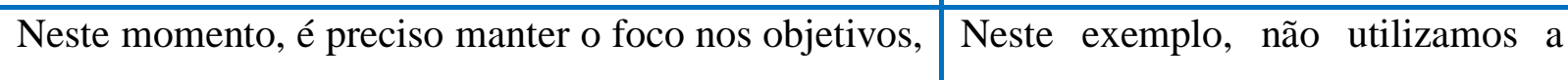


que vieram para resolver hoje.

primeira pessoa do plural (nós) para marcar o distanciamento e mostrar o propósito das partes.

Desculpe-me, não gostaria de interrompê-lo, mas vamos manter o foco no objetivo da audiência.

"desarmador"

Retomada de turno, mais atenuada por início com pedido de desculpas.

Como avisado, anteriormente, este não é o momento para críticas e julgamentos.

Predominantemente, máxima de qualidade e modo.

Bom, infelizmente precisamos mudar de assunto, pelo motivo de nosso objetivo hoje ser...

Predominantemente, máxima de modo e quantidade.

Desculpe-me, não que esta não seja uma questão importante a ser discutida, contudo, pelo nosso tempo, não poderemos tratá-la aqui, pois não faz parte da ação movida pelos senhores.

Por gentileza, vamos voltar a conversar sobre que é o propósito desta mediação.

Predominantemente, máxima de relevância.

\begin{tabular}{|c|c|}
\hline Não vamos fugir do assunto & $\begin{array}{l}\text { Predominantemente, máxima de } \\
\text { quantidade. }\end{array}$ \\
\hline É melhor decidir primeiro o tema anterior & $\begin{array}{l}\text { Predominantemente, máxima de } \\
\text { quantidade e relevância. }\end{array}$ \\
\hline $\begin{array}{l}\text { Com base nos princípios da mediação, não podemos } \\
\text { tratar desses acontecimentos. }\end{array}$ & $\begin{array}{l}\text { Distanciamento do falante e } \\
\text { elemento de argumentação para } \\
\text { mudança de assunto. }\end{array}$ \\
\hline $\begin{array}{l}\text { Desculpe-me, senhores, não posso analisar } \\
\text { documentos, pelo princípio da informalidade, como } \\
\text { disse anteriormente, não posso analisar provas, não é o } \\
\text { objetivo. }\end{array}$ & $\begin{array}{l}\text { Distanciamento do falante e } \\
\text { elemento de argumentação para } \\
\text { mudança de assunto. }\end{array}$ \\
\hline
\end{tabular}

Fonte: adaptação de Brasil (2006), Campato Jr. (2015), Castilho (2014), Dicionário de Sinônimos Online (2019), Kerbrat-Orecchioni (2006), Koch (2011, 2015, 2016a, 2016b 2017), Marcuschi (1986), Urbano (2015). 


\subsection{Enfoque prospectivo}

Cabe destacar que "em vez de ouvir o discurso da parte pensando em quem está certo ou errado, o mediador deve ouvir para identificar quais são os interesses das partes, quais são as questões a serem dirimidas e como estimular as partes a encontrar tais soluções" (BRASIL, 2016, p. 240).

Nessa técnica, é muito relevante que o(a) mediador(a) tente fazer com que as partes procurem ter uma visão positiva de futuro, que deixem os julgamentos e mágoas do passado no passado e criem novas perspectivas para as relações futuras. Para contribuir de forma significativa com essa técnica, alguns conhecimentos da Neurolinguística e Semântica podem ajudar no processo de ressignificação do contexto.

Conforme Meirelles (2017, n.p.):

A PNL ${ }^{10}$ criou um conjunto de pressupostos que fundamentam o enquadre do trabalho terapêutico. São (alguns) deles: "palavras são gatilhos que disparam sensações e emoções", "a linguagem determina a visão de mundo", "as experiências possuem uma estrutura" "toda linguagem é hipnótica".

Com base nestas considerações, podemos perceber o quanto o uso das palavras e seus significados podem transformar o raciocínio humano a partir de proposições positivas, a substituição de palavras negativas ou geradoras de conflitos por palavras otimistas, que podem trazer à tona a memória afetiva, e ainda, em consonância com a referida autora é possível reprogramar a mente ou fazer o ouvinte refletir por meio de uma descrição de cena ou evento, que pode causar emoções ou sensações, guiadas por um falante que saiba fazer as colocações de forma sútil e cortês.

Quadro 10 - Dicas para criar visão de futuro

\begin{tabular}{l|l}
\multicolumn{1}{c|}{ ESTRATÉGIAS/EXEMPLOS DE USO } & \multicolumn{1}{c}{ OBSERVAÇÕES } \\
\hline $\begin{array}{l}\text { Eu vejo que se sente... vamos tentar olhar para esta } \\
\text { situação de outra forma? }\end{array}$ & $\begin{array}{l}\text { Valida o sentimento e propõe uma } \\
\text { nova perspectiva. }\end{array}$ \\
\hline Vocês conseguiriam (poderiam) pensar em ... & $\begin{array}{l}\text { Verbo no pretérito do futuro com } \\
\text { função de atenuador. }\end{array}$ \\
\hline Em relação a isso, que tal pensarmos o que poderia & $\begin{array}{l}\text { Perspectiva de mudança tendo em vista } \\
\text { o futuro. }\end{array}$ \\
ser mudado? & \\
\hline${ }^{10}$ Programação Neurolinguística. &
\end{tabular}


Agora que estamos nesse ponto, vamos analisar e Perspectiva de mudança tendo em vista sugerir possibilidades futuras? o futuro.

Vamos pensar em estratégias (critérios) para
"Nós" como aproximação. mudanças?

Este é um momento muito importante, em razão de estarem tendo a oportunidade de buscarem novas oportunidades.

\begin{tabular}{|c|c|}
\hline $\begin{array}{l}\text { Nós vamos ouvi-los para compreender as } \\
\text { necessidades, mas não estamos buscando culpados, } \\
\text { é importante pensarmos para o futuro. }\end{array}$ & $\begin{array}{l}\text { Atende às necessidades das partes de } \\
\text { serem ouvidas, mas, sugerem o foco } \\
\text { para o futuro. }\end{array}$ \\
\hline $\begin{array}{l}\text { Como sabemos não é possível mudar o passado, } \\
\text { porém, há oportunidade de direcionar nossas } \\
\text { atitudes para o futuro. }\end{array}$ & $\begin{array}{l}\text { Reconhecimento da situação; polidez } \\
\text { textual; rapport. }\end{array}$ \\
\hline Nós & $\begin{array}{l}\text { "Nós e a gente" forma de aproximação; } \\
\text { valor de solidariedade; sugestão. }\end{array}$ \\
\hline $\begin{array}{l}\text { Por mais difíceis que tenham sido os } \\
\text { acontecimentos, não é bom ficar preso ao passado, } \\
\text { por isso temos a oportunidade de tentar modificar } \\
\text { situações e comportamentos futuros. }\end{array}$ & $\begin{array}{l}\text { Reconhecimento da importância dos } \\
\text { fatos ocorridos, todavia, incentivo à } \\
\text { perspectiva de mudança tendo em vista } \\
\text { o futuro. }\end{array}$ \\
\hline $\begin{array}{l}\text { Pensar no futuro, pode ser uma possibilidade de } \\
\text { começar mudanças positivas com base em vivências } \\
\text { negativas que nos ensinaram alguma lição. }\end{array}$ & $\begin{array}{l}\text { Visão de passado como aprendizado e } \\
\text { oportunidade de melhora para o futuro. }\end{array}$ \\
\hline $\begin{array}{l}\text { Passar a acreditar em novas oportunidades é um } \\
\text { grande passo para deixar as situações passadas para } \\
\text { trás. }\end{array}$ & Visão p \\
\hline $\begin{array}{l}\text { Deixar de valorizar as circunstâncias passadas não } \\
\text { quer dizer que não tiveram importância, quer dizer, } \\
\text { apenas, que estamos dando-nos novas chances. }\end{array}$ & $\begin{array}{l}\text { Visão de passado como aprendizado e } \\
\text { oportunidade de melhora para o futuro. }\end{array}$ \\
\hline $\begin{array}{l}\text { Eu vejo que se sentiu... vamos tentar ver esta } \\
\text { situação de outra forma, posso contar com você? }\end{array}$ & $\begin{array}{l}\text { Estrutura indicada para a sessão } \\
\text { individual; estrutura que pode ser } \\
\text { usada para persuadir a parte a } \\
\text { colaborar e se esforçar para tentar ver a } \\
\text { situação de outra perspectiva. }\end{array}$ \\
\hline
\end{tabular}


Fonte: adaptação de Brasil (2006), Campato Jr. (2015), Castilho (2014), Wilton Neto (2017?), Dicionário de Sinônimos Online (2019), Kerbrat-Orecchioni (2006), Koch (2011, 2015, 2016a, 2016b 2017), Marcuschi (1986), Urbano (2015).

Quadro 11 - Motivações para mudança de comportamento e enfoque prospectivo

\section{POR QUE ENFOQUE PROSPECTIVO?}

Não deve haver dúvidas de que quando temos uma decisão dada pelo juiz pode ser uma decisão que não agrade pelo menos uma das partes, e na mediação, esta decisão pode ser tomada por vocês, as partes, o que pode deixá-los mais satisfeitos e não precisarem voltar ao jurídico pelo mesmo motivo.

É importante pensar que não é bom ficar na mão de terceiros, testemunhas e juízes...

Eu creio que a discussão sobre o passado não acrescenta muito, importante é pensar como os dois podem ganhar daqui para frente.

Na mediação, temos como objetivo o ganho para todas as partes, por isso é tão importante pensar no futuro, em novas perspectivas.

Erramos, mas, temos chances de recomeçar.

O que você ganha ficando preso ao passado?

Qual o caminho mais fácil para seguir daqui para frente?

O que você ganha se ceder em algo? E o que você perde se ceder?

Fonte: adaptação de Brasil (2006), Wilton Neto (2017?), Dicionário de Sinônimos Online (2019), Kerbrat-Orecchioni (2006), Koch (2011, 2015, 2016a, 2016b 2017).

\subsection{Teste de realidade}

Devido à relação emocional das partes com o conflito, esse teste tem como objetivo trazer a reflexão de sentimentos internalizados com os fatos ocorridos no conflito, conforme exposto a seguir:

O teste de realidade consiste em estimular a parte a proceder com uma comparação do seu "mundo interno" com o "mundo externo" - como percebido pelo mediador. Como na técnica de inversão de papéis, recomenda-se que se avise à parte que o mediador está aplicando uma técnica de mediação e se aplique prioritariamente em sessões privadas (BRASIL, 2016, p. 240). 
Além disso, cabe salientar as palavras de Takahashi [et al.] (2019, p. 82), sobre o teste de realidade como a "apresentação de uma perspectiva diversa àquela de uma ou de ambas as partes, de maneira a se notar a discrepância entre o que se imagina e o que se costuma ocorrer. É uma forma de fazer a pessoa "voltar para a realidade"”.

Esse mecanismo de tentar fazer a pessoa "voltar à realidade" e refletir as reais capacidades de cumprir com o acordo que está propondo deve ser utilizado por meio de uma linguagem sutil. Nesse caso, seria conveniente o uso das estratégias de atenuação, as quais são chamadas por Fraser (1980) de abrandamento. Trata-se de estratégias para reduzir efeitos indesejados, para não constranger nenhuma das partes e nem as deixar com a impressão de serem desrespeitadas, ou de terem a impressão de que suas ideias são negadas.

Quadro 12 - Dicas para teste de realidade

ESTRATÉGIAS/EXEMPLOS DE USO

Para melhor visualizarmos a situação (a proposta), na mediação, costumamos aplicar uma técnica chamada teste de realidade, é o que faremos agora, tudo bem?

Vou aplicar uma técnica com você que se chama teste de realidade, é uma técnica que nos ajuda a compreender bem a ideia e confirmar todas as possibilidades.

\section{OBSERVAÇÕES}

Aviso sobre a aplicação da técnica.

Aviso sobre a aplicação da técnica.

O emprego da estrutura "nós" causa aproximação e evidencia para a parte que o mediador também precisa compreender.

Aviso sobre a aplicação da técnica.

Validação de sentimentos e convalidação destes com a realidade dos fatos.

Empoderamento das partes.

Como o senhor acha que esta questão será resolvida pelo juiz? E como gostaria que fosse resolvido por vocês? Como podemos organizar essas ideias $\mathrm{e}$ ver as possibilidades de cumprir um possível acordo.

Como vai funcionar sua realidade com esta proposta?

Visualização das condições reais de cumprimento da proposta. 


\begin{tabular}{|c|c|}
\hline E na prática, como vai ser...? & $\begin{array}{l}\text { Visualização das condições reais } \\
\text { de cumprimento da proposta. }\end{array}$ \\
\hline E no dia a dia, como será...? & $\begin{array}{l}\text { Visualização das condições reais } \\
\text { de cumprimento da proposta. }\end{array}$ \\
\hline $\begin{array}{l}\text { Se futuramente esse sentimento (pensamento) mudar, } \\
\text { como a senhora vai se sentir? }\end{array}$ & $\begin{array}{l}\text { A partícula "se" causa ideia de } \\
\text { possibilidades. }\end{array}$ \\
\hline $\begin{array}{l}\text { Vamos tentar ilustrar as reais possibilidades da (sua) } \\
\text { proposta? }\end{array}$ & $\begin{array}{l}\text { Visualização das condições reais } \\
\text { de cumprimento da proposta, por } \\
\text { meio da ilustração. }\end{array}$ \\
\hline $\begin{array}{l}\text { Acredito que seria bom exemplificarmos e pontuarmos, } \\
\text { neste papel, a possibilidade de desenvolvimento deste } \\
\text { acordo... }\end{array}$ & $\begin{array}{l}\text { Visualização das condições reais } \\
\text { de cumprimento da proposta, por } \\
\text { meio da exemplificação. }\end{array}$ \\
\hline Se examinarmos... & $\begin{array}{l}\text { Atenuador para visualização das } \\
\text { condições reais de cumprimento } \\
\text { da proposta. }\end{array}$ \\
\hline Se analisarmos bem... & $\begin{array}{l}\text { Atenuador para visualização das } \\
\text { condições reais de cumprimento } \\
\text { da proposta. }\end{array}$ \\
\hline $\begin{array}{l}\text { "Se estivesse na situação da outra parte, aceitaria as } \\
\text { propostas que você está fazendo agora ou esperaria que } \\
\text { lhe fosse oferecido mais?" (MOORE, 1998, p. 243). }\end{array}$ & $\begin{array}{l}\text { Inversão de papéis implícita para } \\
\text { validar a seriedade da proposta. }\end{array}$ \\
\hline
\end{tabular}

Fonte: adaptação de Brasil (2006), Campato Jr. (2015), Castilho (2014), Dicionário de Sinônimos Online (2019), Kerbrat-Orecchioni (2006), Koch (2011, 2015, 2016a, 2016b 2017), Marcuschi (1986), Moore (1998), Urbano (2015).

\subsection{Validação de sentimentos}

Tem como objetivo, a identificação dos sentimentos demonstrados por meio do uso da linguagem verbal e/ou corporal. Nessa técnica, o mediador pode recorrer à paráfrase indicada por Rosenberg (2006), na CNV (Comunicação não violenta), como instrumento para validação. E pode, também, lançar mão do Princípio da Cooperação e das Máximas conversacionais, citadas na técnica de geração de opções, para tentar fazer com que o falante explicite de modo objetivo e claro quais seus reais sentimentos e necessidades. 
Quadro 13 - Dicas para validar sentimentos

\begin{tabular}{|c|c|}
\hline ESTRATÉGIAS/EXEMPLOS DE USO & OBSERVAÇÕES \\
\hline Pelo que percebo (me parece) se senti..., correto? & Atenuador. \\
\hline $\begin{array}{l}\text { Gostaria de saber se compreendi bem, se a senhora se sente } \\
\text { desconfortável (magoada, triste...) com essa circunstância, é } \\
\text { isso mesmo? }\end{array}$ & Aten \\
\hline Em decorrência do que a senhora disse, parece-me que... & $\begin{array}{l}\text { Consideração relativa ao que } \\
\text { foi dito anteriormente. }\end{array}$ \\
\hline $\begin{array}{l}\text { Tenho a impressão de que esta (se sente)..., compreendi } \\
\text { bem? }\end{array}$ & Atenuador. \\
\hline A impressão que tenho é que..., estou certo(a)? & Atenuador. \\
\hline $\begin{array}{l}\text { Parece-me que o senhor (você) se sente } \_ \text {com esta } \\
\text { situação, e teria a necessidade de } \_ \text {entendi } \\
\text { certo? }\end{array}$ & Atenuador. \\
\hline esentar-se. & $\begin{array}{l}\text { Alguns sinônimos para serem } \\
\text { usados no lugar de "sente- } \\
\text { se". }\end{array}$ \\
\hline $\begin{array}{l}\text { Para que eu possa compreender melhor, gostaria que me } \\
\text { dissesse de forma bem objetiva, se possível, pode ser em uma } \\
\text { palavra, qual seu sentimento (qual sentimento mais te } \\
\text { incomoda) diante dessa situação e qual sua maior } \\
\text { necessidade? }\end{array}$ & $\begin{array}{l}\text { Estratégia de } \begin{array}{r}\text { atenuação; } \\
\text { Princípio da } \\
\text { (Quantidade, }\end{array} \\
\text { Modo, Relação). }\end{array}$ \\
\hline
\end{tabular}

Fonte: adaptação de Brasil (2006), Campato Jr. (2015), Castilho (2014), Dicionário de Sinônimos Online (2019), Kerbrat-Orecchioni (2006), Koch (2011, 2015, 2016a, 2016b 2017), Marcuschi (1986), Urbano (2015). 


\section{OUTRAS SUGESTÕES PARA MOMENTOS DIVERSOS DA MEDIAÇÃO E CONCILIAÇÃO}

Além das técnicas apresentadas, seguem algumas dicas que também podem contribuir com o procedimento da mediação/conciliação. Essas estratégias foram selecionadas com base na identificação de necessidades aparentes no contexto em estudo e por fazerem parte das interações humanas, especialmente, as interações orais.

Quadro 14 - Estruturas linguísticas a serem evitadas

\begin{tabular}{|c|c|c|}
\hline EVITAR & OBSERVAÇÕES & OPTE POR \\
\hline Hein?! & $\begin{array}{l}\text { Uma forma de indicar incompreensão do que } \\
\text { foi dito, todavia, pode parecer desrespeitoso, } \\
\text { ou informal demais. }\end{array}$ & $\begin{array}{l}\text { Pode repetir, por favor? } \\
\text { Como disse? } \\
\text { Desculpe, como? }\end{array}$ \\
\hline Sim; certo; bom. & $\begin{array}{l}\text { Sinal de escuta, entretanto, pode causar } \\
\text { impressão de concordância, emissão de valor. }\end{array}$ & $\begin{array}{l}\text { Estou escutando, estou } \\
\text { compreendendo o que } \\
\text { diz. }\end{array}$ \\
\hline $\begin{array}{l}\text { Simplesmente, } \\
\text { só. }\end{array}$ & $\begin{array}{l}\text { Minimizar. Pode invalidar a fala e mostrar } \\
\text { descrédito para o que foi dito, o que poderia } \\
\text { causar uma visão negativa do interlocutor. }\end{array}$ & $\begin{array}{l}\text { Poderia falar mais sobre } \\
\text { (explicar } \\
\text { detalhadamente); algo } \\
\text { mais a acrescentar? }\end{array}$ \\
\hline $\begin{array}{l}\text { Vocês seriam } \\
\text { capazes de tentar } \\
\text { mudar? }\end{array}$ & Rude. & $\begin{array}{l}\text { Vocês } \\
\text { interesse...?; sentem-se } \\
\text { preparados para...? }\end{array}$ \\
\hline $\begin{array}{l}\text { Conselhinho, } \\
\text { ajudinha, } \\
\text { perguntinha. }\end{array}$ & $\begin{array}{l}\text { Diminutivo. } \\
\text { Muito informal para o contexto. }\end{array}$ & $\begin{array}{l}\text { Conselho; } \\
\text { pergunta. }\end{array}$ \\
\hline $\begin{array}{l}\text { Nós vamos } \\
\text { solucionar } \quad \text { a } \\
\text { questão... }\end{array}$ & Os senhores estão aqui para tentar... & $\begin{array}{l}\text { Não usar "nós" como se } \\
\text { fossem fazer parte da } \\
\text { auto composição. }\end{array}$ \\
\hline $\begin{array}{l}\text { Nós vamos } \\
\text { chegar a... }\end{array}$ & $\begin{array}{l}\text { Nós (mediadores(as)) estamos aqui para tentar } \\
\text { facilitar a comunicação. }\end{array}$ & $\begin{array}{l}\text { Destacar o papel de } \\
\text { facilitador do diálogo. }\end{array}$ \\
\hline $\begin{array}{l}\text { Estamos aqui } \\
\text { para resolver... }\end{array}$ & $\begin{array}{l}\text { Estamos aqui com intuito de contribuir para o } \\
\text { diálogo dos senhores... }\end{array}$ & $\begin{array}{l}\mathrm{O}(\mathrm{a}) \text { mediador(a) não } \\
\text { resolve pelas partes. }\end{array}$ \\
\hline
\end{tabular}




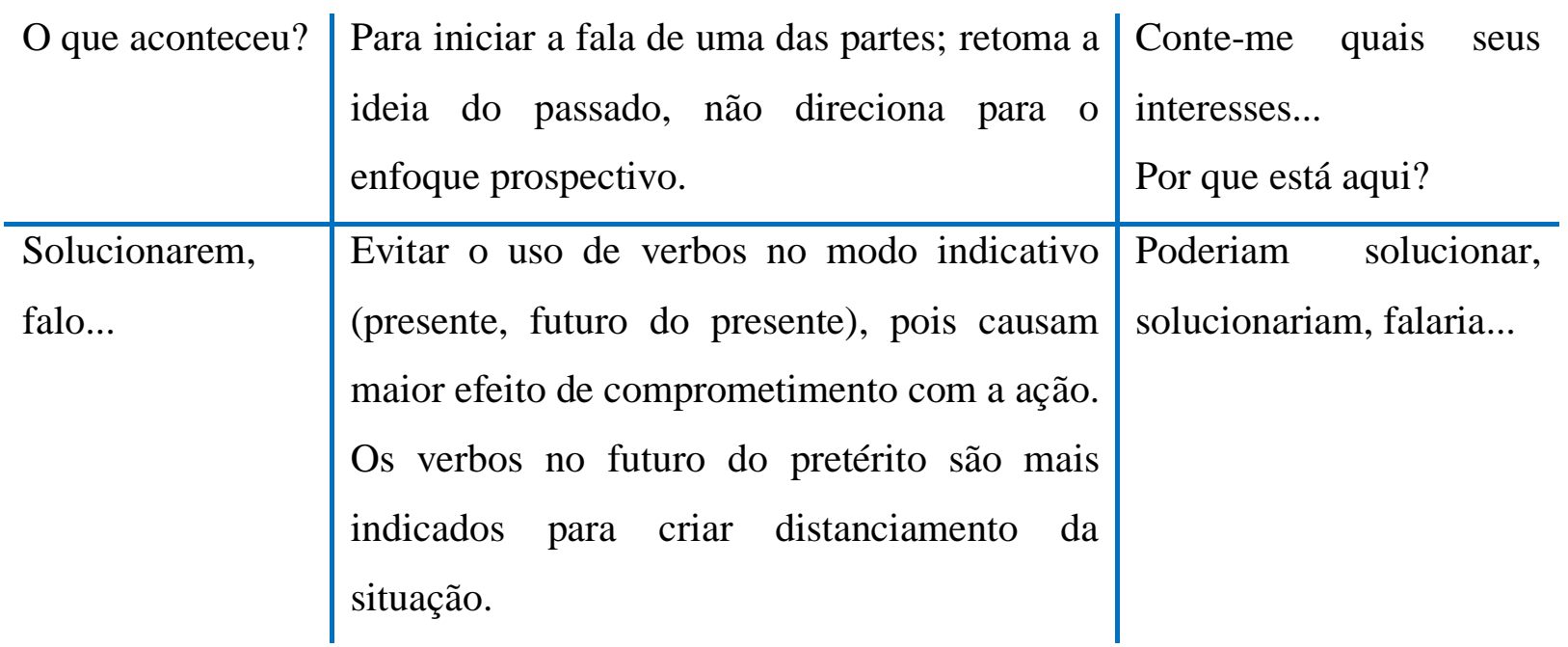

Fonte: adaptação de Brasil (2006), Campato Jr. (2015), Castilho (2014), Dicionário de Sinônimos Online (2019), Kerbrat-Orecchioni (2006), Koch (2011, 2015, 2016a, 2016b 2017), Marcuschi (1986), Urbano (2015).

Quadro 15 - Dicas para rapport

\begin{tabular}{|c|c|}
\hline DICA DE USO & OBSERVAÇÃO \\
\hline Elogiar; concordar; pedir opinião. & $\begin{array}{l}\text { Produz efeito de aproximação, ou } \\
\text { seja, cria rapport. }\end{array}$ \\
\hline Empregar você no lugar da $3^{\text {a }}$ pessoa indeterminada & $\begin{array}{l}\text { Produz efeito de aproximação, ou } \\
\text { seja, cria rapport. }\end{array}$ \\
\hline $\begin{array}{l}\text { Gostaria de saber se compreendi bem __ dessa forma, } \\
\text { a senhora está se sentindo___ por isso (possivelmente) } \\
\text { a senhora teria a necessidade __ o que acha de } \\
\text { pensarmos numa proposta, fazer um pedido conforme a } \\
\text { sua necessidade, para tentar chegar a uma solução. }\end{array}$ & $\begin{array}{l}\text { Paráfrase proposta por Rosenberg } \\
\text { (2006), CNV (Comunicação Não } \\
\text { Violenta). }\end{array}$ \\
\hline $\begin{array}{l}\text { Parece que você está se sentindo __ porque gostaria } \\
\text { de }\end{array}$ & $\begin{array}{l}\text { Paráfrase proposta por Rosenberg } \\
\text { (2006), CNV (Comunicação Não } \\
\text { Violenta). }\end{array}$ \\
\hline $\begin{array}{l}\text { Uma afirmativa como "Você não me ouviu direito", } \\
\text { "Não foi isso o que eu disse" ou "Você está me } \\
\text { interpretando mal" pode facilmente fazer Pedro pensar } \\
\text { que está sendo repreendido (ROSENBERG, 2006, p. } \\
\text { 114). }\end{array}$ & $\begin{array}{l}\text { A estrutura "você" nas frases, } \\
\text { transferi a responsabilidade da } \\
\text { incompreensão para o ouvinte, isso } \\
\text { pode quebrar o rapport. }\end{array}$ \\
\hline & A es \\
\hline
\end{tabular}


vejo que não consegui ser tão clara quanto gostaria. Então, deixe-me tentar de novo" (ROSENBERG, 2006, p. 114).

Poderíamos perguntar isso dessa maneira: "Gostaria que você me dissesse como se sente a respeito do que acabei de falar e suas razões para sentir-se assim" (ROSENBERG, 2006, p. 115).

"Quero que você me diga como se sente a respeito do que aconteceu e o que gostaria que eu tivesse acontecido de modo diferente" (adaptação de ROSENBERG, 2006, p. 131).

"Falei sem pensar. Não queria ter reagido assim àquilo que você disse" (MORRISON, 2019, p. 59). transferi a responsabilidade para quem está falando e não para o ouvinte.

Sugestão de uso:
recontextualização, validação de sentimentos, audição de propostas implícitas.

Sugestão de uso:
recontextualização, validação de sentimentos, audição de propostas implícitas.

"Pedidos de desculpas, promove compreensão e perdão" (MORRISON, 2019, p. 59).

Sugestão de uso: audição de propostas implícitas, arrependimento.

"Me sinto triste e preocupada. Quero esclarecer o malentendido entre nós" (MORRISON, 2019, p. 59).

"Pedidos de desculpas, promove compreensão e perdão" (MORRISON, 2019, p. 59).

Sugestão de uso: audição de propostas implícitas, arrependimento.

Fonte: adaptação de Brasil (2006), Campato Jr. (2015), Castilho (2014), Wilton Neto (2017?), Dicionário de Sinônimos Online (2019), Kerbrat-Orecchioni (2006), Koch (2011, 2015, 2016a, 2016b 2017), Marcuschi (1986), Morrison (2019), Rosenberg (2006) Urbano (2015).

Quadro 16 - Exemplos de Marcadores Discursivos

\begin{tabular}{l|l}
\multicolumn{1}{c|}{ MARCADORES DISCURSIVOS } & \multicolumn{1}{c}{ OBSERVAÇÕES } \\
\hline E aí? Tudo bem? Escuta, Viu? Vem & Para iniciar um diálogo. \\
cá & \\
\hline Bom, é o seguinte... Quanto a, Em & Para iniciar um assunto.
\end{tabular}


relação a, no que diz respeito a..., A respeito de...

Inicialmente, primeiramente, em Para subdividir os assuntos a serem tratados. segundo lugar, em seguida.

E além disso, outra coisa, e tem mais, Para acrescentar informações ao assunto. pera aí.

Aí, então, depois, aí então, depois Pode ocorrer no início e final de fala. então, agora, veja

Percebeu? Entendeu? Viu? Né? Que Normalmente acontece no início e final de fala. Para tal? Que acha? E você? Não é? Sabe? Compreende? Não é mesmo? Sabe? cobrar a colaboração do ouvinte.

Busca de aprovação discursiva, o falante quer ter certeza de que está acompanhando sua fala, contudo, o mediador ou conciliador não deve manifestar concordância como uso do "sim", em consequência a outra parte pode se sentir prejudicada.

\begin{tabular}{|c|c|}
\hline $\begin{array}{l}\text { Tá, está bem, ok, certo, claro, } \\
\text { evidente, sem dúvida, exato }\end{array}$ & Expressa concordância. \\
\hline $\begin{array}{l}\text { Não, isso não, assim também não, } \\
\text { não é bem assim }\end{array}$ & Expressa discordância. \\
\hline Será? É mesmo? Tem certeza? & Expressa dúvida. \\
\hline Ah, eh, é..., uhn... & Hesitação (rupturas na fala). \\
\hline $\begin{array}{l}\text { Fazendo um parêntese; desculpe } \\
\text { interromper, mas...; antes que eu me } \\
\text { esqueça; a propósito; por falar } \\
\text { nisso...; já que mencionou isso... }\end{array}$ & $\begin{array}{l}\text { Início de uma digressão (mudança de assunto, } \\
\text { acréscimo de informação). }\end{array}$ \\
\hline $\begin{array}{l}\text { Voltando ao assunto, fechando os } \\
\text { parênteses, voltando ao que eu (você) } \\
\text { estava dizendo. }\end{array}$ & $\begin{array}{l}\text { Fim de uma digressão (retomada de assunto, } \\
\text { acréscimo de informação). }\end{array}$ \\
\hline $\begin{array}{l}\text { Até, mesmo, também, inclusive, em } \\
\text { acréscimo. }\end{array}$ & Ideia de inclusão. \\
\hline Só, somente, apenas. & Ideia de Exclusão. \\
\hline Aliás, ou melhor. & Ic \\
\hline
\end{tabular}


Em última análise, por tais razões, Ideia de Conclusão.

Para terminar

Por exemplo, só para ilustrar, só para

Para ilustração, esclarecer ideias.

exemplificar, em outras palavras.

Suponho que, creio que, eu acho que, Atenuação; distanciamento do falante.

o que me parece, tenho a impressão.

\begin{tabular}{lll|l}
\hline Pode & ser, & possivelmente, & Atenuação; distanciamento do falante.
\end{tabular}

provavelmente, é possível que, talvez.

\begin{tabular}{l|l}
\hline Gostaria, poderia. & Tempo verbal - atenuação. \\
\hline Desculpe-me por interrompê-los, & Atenuação, retomada do direito a fala. \\
mas é preciso respeitar a vez do outro & \\
falar... & \\
\hline Se me permiti dizer... & Atenuação para dar opinião e/ou sugestão. \\
\hline Felizmente, lamentavelmente. & Avaliação de eventos, ações, situações. \\
\hline É bom lembrar que, voltando ao & Interrupção ou reintrodução do assunto. \\
assunto (tema). & \\
\hline $\begin{array}{l}\text { Como já disse anteriormente, como já } \\
\text { frisei anteriormente. }\end{array}$ & Reforço de ideia e retomada de assunto. \\
\hline Agora que estamos neste ponto. & Armação de quadro tópico (assunto). \\
\hline "eu não sei muita coisa sobre isso, & Atenuação e preservação da face. \\
mas...; veja bem... posso estar \\
enganado... mas; sem querer ser \\
grosseiro e sem querer te corrigir... \\
creio que...
\end{tabular}

Fonte: adaptação de Brasil (2006), Campato Jr. (2015), Castilho (2014), Wilton Neto (2017?), Dicionário de Sinônimos Online (2019), Kerbrat-Orecchioni (2006), Koch (2011, 2015, 2016a, 2016b 2017), Marcuschi (1986), Urbano (2015).

Quadro 17 - Sugestões para iniciar a audiência de Mediação e Conciliação

\section{INICIANDO A MEDIAÇÃO}

Bem, doutores(as), neste primeiro momento é importante que deixem seus clientes falarem, após a fala de cada um, passaremos a voz para seus respectivos advogados. Então, fulano, 
diga-nos por qual motivo está aqui...

Este momento é muito importante para serem ouvidos e tentarmos buscar uma solução positiva para todos, dito isto, Fulano, por favor, explique por qual motivo está aqui hoje?

O que te trouxe aqui hoje...

Conte-nos porque está aqui hoje...

Qual a pretensão do senhor neste encontro...

Fonte: adaptação de Brasil (2006).

Quadro 18 - Sugestões de sinônimos e palavras com acepção positiva

\begin{tabular}{l|l|lr}
\multicolumn{1}{c|}{ EVITAR } & \multicolumn{1}{|c|}{$\begin{array}{c}\text { SUBSTITUIR POR: } \\
\text { (+) POSITIVAS }\end{array}$} & \multicolumn{2}{c}{ OBSERVAÇÃo } \\
\hline Acordo & $\begin{array}{l}\text { Resolução para a situação; } \\
\text { solução para este contexto; } \\
\text { reconciliação. }\end{array}$ & $\begin{array}{l}\text { Como não é objetivo } \\
\text { principal, } \\
\text { "recomendável” qão que ó o } \\
\text { mediador fale em "acordo" a } \\
\text { todo o momento. }\end{array}$ \\
\hline Processo & $\begin{array}{l}\text { Questão, assunto, ponto, } \\
\text { demanda, objetivo. }\end{array}$ & $\begin{array}{l}\text { Palavras com acepções } \\
\text { positivas. }\end{array}$ \\
\hline Problema & $\begin{array}{l}\text { Caso, fato, situação, adversidade, } \\
\text { infortúnio, acontecimento, } \\
\text { acontecido. }\end{array}$ & $\begin{array}{l}\text { Pode ser visto como uma } \\
\text { oportunidade de solução. }\end{array}$ \\
\hline Conflito & $\begin{array}{l}\text { Aborrecimento, } \\
\text { desentendimento, indisposição. }\end{array}$ & $\begin{array}{l}\text { Palavras com acepções } \\
\text { positivas. }\end{array}$ \\
\hline Lide & $\begin{array}{l}\text { Ação, demanda, causa, } \\
\text { solicitação. }\end{array}$ & $\begin{array}{l}\text { Palavras com acepções } \\
\text { positivas. }\end{array}$ \\
\hline Ré ou réu & $\begin{array}{l}\text { Parte (parte que solicitou, parte } \\
\text { que foi solicitada), senhor, } \\
\text { senhora, você, nomes próprios. }\end{array}$ & $\begin{array}{l}\text { Além do uso comum de parte } \\
\text { requerida e requerente; parte } \\
\text { autora. }\end{array}$ \\
\hline
\end{tabular}

Fonte: adaptação de Brasil (2006), Dicionário de Sinônimos Online (2019).

\subsection{SIMPLIFICAÇÃO DA LINGUAGEM}

De forma geral, o contexto de meios alternativos para resolução de conflitos, especialmente, a mediação e a conciliação têm como objetivo priorizar as partes, empoderálas e gerar uma cultura de pacificação social. Nesse sentido, ao considerar a relevância dada às partes, é preciso ter em vista, também, a facilitação da linguagem. Assim, elencamos alguns termos jurídicos comumente utilizados nas sessões de mediação e conciliação, que poderiam ser simplificados para a compreensão das partes e cooperação para o efetivo entendimento da interação. 
Quadro 19 - Sugestões de sinônimos para facilitação da linguagem

\begin{tabular}{l|l} 
TERMO JURÍDICO & \multicolumn{1}{|c}{ LINGUAGEM SIMPLIFICADA } \\
\hline Título Executivo & Compromisso diante da lei; documento reconhecido por lei \\
\hline Homologação & Aprovação, aceitação, anuência, concordância \\
\hline Juntado & Inserido, incluído \\
\hline Citado & Chamado(a) (convocado(a)) para a sessão \\
\hline Custas & Despesas da ação ou processo \\
\hline Composição & Acordo; acerto \\
\hline Lide & Causa, demanda
\end{tabular}

Fonte: adaptação de Brasil (2006), Dicionário de Sinônimos Online (2019).

\subsection{COMUNICAÇÃO EMPÁTICA}

No que se refere à competência linguística exigida para o trabalho com a mediação e conciliação, cabe evidenciar o estudo sobre a Comunicação Não Violenta, desenvolvido pelo psicólogo Rosenberg (2006). Em sua obra, salienta a importância da empatia e desenvolve instruções de como podemos nos comunicar e atender às nossas necessidades sem precisar ofender ninguém. Além disso, o autor (2006) propõe uma comunicação sem julgamentos e ressalta uma lista de sentimentos que podem auxiliar para uma comunicação empática e outra lista de sentimentos que podem causar conflitos, baseada em julgamentos. Dessa forma, elencamos alguns desses exemplos, de Rosenberg (2006), que podem contribuir de maneira significativa com o trabalho do mediador, particularmente, para a validação de sentimentos.

Quadro 20 - Listagem de sentimentos - Comunicação Não Violenta

$$
\text { SUGESTÕES DE ROSENBERG (2006) - CNV }{ }^{11}
$$

\section{SENTIMENTOS POSITIVOS PARA NECESSIDADES ATENDIDAS}

$$
\text { Agradecido }
$$

Alegre; feliz

$$
\text { Aliviado }
$$

Amoroso

\section{Calmo}

\footnotetext{
${ }^{11}$ Comunicação Não Violenta
} 
Compreendido

Compreensivo

Confiante

Despreocupado

Entusiasmado

Gratificado, agradecido

Honrado

Maravilhado

Reconhecido

Satisfeito

SENTIMENTOS NEGATIVOS PARA NECESSIDADES NÃO ATENDIDAS

Abandonado

Abatido; desanimado; aborrecido; chateado

Aflito, apreensivo

Angustiado

Ansioso

Arrependido

Assustado

Cansado

Carregado

Chateado, magoado

Confuso, receoso

Desamparado

Desapontado, frustrado

Desconfortável

Descontente

Humilhado; envergonhado; constrangido; desconfortável

Ignorado; desconsiderado; deixado; desmerecido; esquecido

Incomodado

Incompreendido

Ingrato 
Insatisfeito

Inseguro; desesperançoso; surpreso; surpreendido; abalado

Nervoso; impaciente

Preocupado, apreensivo

Rude; descortês; indelicado

Solitário

Temeroso

Triste; descontente

Como interpretamos OS OUTROS e não como NOS SENTIMOS: palavras a serem

evitadas, porque a carga negativa é direcionada à outra parte, ou seja, pode estimular julgamento e/ou culpa.

\begin{tabular}{l}
\hline Ameaçado \\
\hline Atacado \\
\hline Coagido \\
\hline Criticado \\
\hline Desacreditado \\
\hline Desapontado \\
\hline Enganado \\
\hline Intimidado \\
\hline Mal compreendido \\
\hline Maltratado \\
\hline Menosprezado \\
\hline Pressionado \\
\hline Provocado \\
\hline Rejeitado \\
\hline Traído \\
\hline Usado
\end{tabular}

ALGUMAS NECESSIDADES: foco nas relações interpessoais

Realizações pessoais

Celebrar vitórias ou comover-se por perdas

Aceitação 
Compreensão

\begin{tabular}{l}
\hline Amor \\
\hline Companheirismo \\
\hline Confiança \\
\hline Consideração \\
\hline Honestidade \\
\hline Proximidade \\
\hline Respeito \\
\hline Segurança emocional \\
\hline Lazer
\end{tabular}

Fonte: adaptação Rosenberg (2006)

\subsection{GESTO}

A linguagem gestual acompanha a linguagem verbal, assim, não podemos deixá-la de lado, entendemos que o falante expõe sua intencionalidade pela mensagem que transmite, seja falada ou escrita, de maneira implícita ou explícita; em consonância com Koike (2017), os gestos reforçam essa intencionalidade, por isto, acreditamos que seja relevante para o mediador ter conhecimento de algumas expressões corporais comuns do comportamento humano e, que possam colaborar para interpretação das intenções de seus interlocutores no contexto da mediação e conciliação, desse modo, frisamos, no quadro a seguir, definições de Weil (2011), sobre os sinais emitidos pela linguagem corporal.

Quadro 21 - Linguagem Corporal

\section{LINGUAGEM CORPORAL E PARALINGUÍSTICA}

Abdômen (analogia ao boi)

Tórax (analogia ao leão)

Cabeça (analogia à águia)
OBSERVAÇÕES

Vida instintiva e vegetativa
Vida emocional Vida mental (intelectual $e$ espiritual)

Consciência e domínio dos
três inconscientes anteriores

Recusa, negação 


\begin{tabular}{|c|c|}
\hline Abdômen encolhido & Aceitação \\
\hline Tórax estufado & $\begin{array}{l}\text { Elevação (preponderância) } \\
\text { do EU }\end{array}$ \\
\hline Tórax encolhido & EU diminuído, inseguro \\
\hline Tórax alinhado & Eu em equilíbrio \\
\hline Tórax (aumento da respiração) & Tensão e forte emoção \\
\hline Tórax (suspiros) & Ansiedade e angústia \\
\hline Cabeça erguida & Aumento do controle mental \\
\hline Cabeça baixa & $\begin{array}{l}\text { Indivíduo controlado por } \\
\text { estímulos externos }\end{array}$ \\
\hline Cabeça alinhada & Controle normal da mente \\
\hline Bolsa (ou outro objeto no colo) & $\begin{array}{l}\text { A pessoa não se sente à } \\
\text { vontade }\end{array}$ \\
\hline Bolsa (ou outro objeto deixado de lado) & $\begin{array}{l}\text { A pessoa já se sente à } \\
\text { vontade, confiante no } \\
\text { ambiente }\end{array}$ \\
\hline $\begin{array}{l}\text { Sorriso: canto da boca para cima; costas curvadas e cabeça } \\
\text { encolhida entre os ombros; músculo das pálpebras contraído; } \\
\text { lábios comprimidos; queixo apoiado nas mãos }\end{array}$ & Maldade \\
\hline $\begin{array}{l}\text { Sorriso: sorriso unilateral, singelo; distensão e contração do } \\
\text { músculo da pálpebra; músculo de apenas um lado da boca } \\
\text { elevado; lábios fechados }\end{array}$ & Forçado, submisso \\
\hline $\begin{array}{l}\text { Sorriso: canto da boca curvado; tórax evidente; tronco } \\
\text { inclinado para trás; testa frangida para cima; lábios fechados }\end{array}$ & Desprezo \\
\hline $\begin{array}{l}\text { Sorriso: cabeça alinhada; lábios abertos; olhar claro; sem } \\
\text { apoiar o queijo nas mãos }\end{array}$ & Básico, positivo \\
\hline Corpo (tenso, esticado) inclinado para trás & Recuo, rejeição, afastamento \\
\hline $\begin{array}{l}\text { Corpo (relaxado, descontraído, apoiado em algum objeto que } \\
\text { esteja atrás, ex.: cadeira, parede...) inclinado para trás }\end{array}$ & Aceitação, concordância \\
\hline Braço cruzado diante do tórax & Não aceitação \\
\hline Tronco para frente & $\begin{array}{l}\text { Aceitação, desejo de } \\
\text { "avançar" }\end{array}$ \\
\hline
\end{tabular}




\begin{tabular}{l|l} 
Mão fechada & Não quer ceder \\
\hline Mão aberta & Aceitação, concordância \\
\hline Olhar nos olhos & $\begin{array}{l}\text { Firmeza, } \\
\text { contentamento }\end{array}$ \\
\hline Pés ancorados & Resistência \\
\hline Mão sacudida em direção à boca (de quem fala) & "Engula isso" \\
\hline Sentar na beira & Pressa \\
\hline Ombros tensionados com a cabeça encolhida entre eles & Culpa, proteção \\
\hline Sobrancelhas levantadas & Surpresa \\
\hline Sobrancelhas franzidas & Reprovação \\
\hline Puxar (cabelos) & Puxar pelas ideias \\
\hline Mãos que se movimentam o tempo todo: rabiscam, mexem & Tensão \\
\hline com/em tudo & \\
\hline Mãos estendidas, palmas para cima & Recebo, aceito \\
\hline Lado direito & Da razão \\
\hline Lado esquerdo & Da emoção \\
\hline
\end{tabular}

Fonte: adaptação Weil (2011). 


\section{PRÉVIA COM ADVOGADOS E DECLARAÇÃO DE ABERTURA}

A prévia com os advogados e a declaração de abertura são momentos muito importantes para as sessões de mediação e conciliação, é a oportunidade de acolher os advogados e as partes, estabelecer as regras de andamento do procedimento, mas nem sempre é necessário que seja feita de forma extensa. Pela diversidade de configurações das audiências, algumas incluem todas as partes com ou sem advogados; outras há apenas a presença de advogados e prepostos, além disso, o tempo da mediação é muito maior que o tempo da conciliação e, por isso, é relevante que sejam realizadas de formas distintas, atendendo à demanda de cada contexto.

É muito comum nas audiências de conciliação, a presença de advogados e prepostos que sempre participam em um mesmo CEJUSC, ou que já conhecem bem o procedimento, ou até profissionais que estão na audiência, apenas, para cumprir o protocolo, visto que não dispõem de propostas ou possibilidade de negociação. Dessa forma, indicamos uma declaração de abertura breve, contudo, que não deixe de ser feita, especialmente quando há a presença de uma das partes ou ambas e que não conhecem os trâmites do procedimento. Assim, oferecemos algumas sugestões de declaração de abertura, entretanto, cada mediador(a) poderá criar e adaptar sua própria forma de fazer a declaração.

PRÉVIA COM OS ADVOGADOS: advogados que não conhecem a mediação

Bom dia (Boa tarde), doutores(as). Muito obrigada pela presença dos(as) senhores(as). Já participaram ou conhecem a mediação?

De forma breve, doutores, a mediação tem como objetivo a retomada do diálogo. É uma linha de conduta no âmbito jurídico que visa à pacificação social, então, o foco é dar voz às partes e tentar a autocomposição por meio do reestabelecimento do diálogo, que eles possam refletir e decidir algo que seja positivo para ambos.

A presença dos(as) senhores(as) é de extrema relevância. Sabemos que muitas vezes possuem a agenda cheia, muitos compromissos, porém, pedimos a paciência e a colaboração para que nos ajudem a trabalhar a lide sociológica com seus respectivos clientes, ou seja, trabalhar as questões relacionadas aos sentimentos e necessidades das partes, e que possam utilizar o conhecimento jurídico para esclarecer as dúvidas deles, visto que a mediação tem como um dos princípios a decisão informada. Por isso, advogados são muito bem-vindos para mediação e gostaríamos que os(as) senhores(as) dessem créditos para nosso trabalho. 
Como de costume, realizamos esta conversa inicial com os advogados para esclarecer dúvidas, confirmar se está tudo certo com os honorários, se os senhores precisam de um tempo pra resolver esta questão com o cliente, pois nosso objetivo não é de forma nenhuma atrapalhar vossos trabalhos e ganhos em relação à causa.

Alguma dúvida?

Chamaremos as partes agora, peço licença aos(as) doutores(as) para fazer uma declaração de abertura um pouco mais detalhada, para que não haja dúvidas sobre o procedimento.

PRÉVIA COM OS ADVOGADOS: advogados que conhecem a mediação

Bom dia, doutores(as). Já participaram ou conhecem a mediação?

Bem, considerando que os senhores já conhecem o procedimento, gostaria de agradecê-los pela presença. Quero ressaltar a importância de tê-los aqui, sabemos que muitas vezes possuem a agenda cheia, muitos compromissos, ainda assim, pedimos a contribuição para que nos ajudem a trabalhar a lide sociológica com seus respectivos clientes, ou seja, trabalhar as questões relacionadas aos sentimentos e necessidades das partes, e que possam utilizar o conhecimento jurídico para esclarecer as dúvidas deles, visto que a mediação tem como um dos princípios básico a decisão informada.

Como de costume, realizamos essa conversa inicial com os advogados para esclarecer dúvidas, e também, confirmar se está tudo certo com os honorários, se os senhores precisam de um tempo pra resolver essa questão com o cliente, tendo em vista que nosso objetivo não é de forma nenhuma atrapalhar seus trabalhos e ganhos com relação à causa.

Alguma dúvida?

Chamaremos as partes agora, peço licença aos(as) doutores(as) para fazer uma declaração de abertura um pouco mais detalhada, para que não haja dúvidas sobre o procedimento.

DECLARAÇÃO DE ABERTURA 1: ampliada

Bom dia. Gostaria de iniciar esta sessão de mediação agradecendo pela presença de todos, pelo empenho que fizeram para estarem aqui; gostaria, também, de apresentar-me, sou mediadora. 
Ao fundo nós temos os(as) observadores(as), que são mediadores (as) em formação e estão aqui para analisar o nosso desempenho enquanto mediadores(as), não observarão o caso dos senhores, hoje.

Estão bem acomodados? Pergunto, porque o tempo de duração desta sessão pode ser de até uma hora e meia, então, é importante que se sintam bem acomodados, se precisar falar com alguém antes de iniciarmos a mediação, disponibilizamos de um tempinho para ligar ou enviar algum recado, se quiserem beber água, fiquem à vontade.

$\mathrm{Na}$ mediação, temos alguns princípios e gostaria de destacar para os senhores a imparcialidade e neutralidade, que é a garantia de realizarmos nosso trabalho sem favorecer nenhuma das partes. Dito isto, gostaria de confirmar se alguém de vocês nos conhece de algum lugar, se já tivemos alguma relação próxima que pode comprometer essa sessão?

Como parte do andamento da mediação, podem me confirmar seus nomes e como gostariam de ser chamados?

Como havia comentado, nós mediadores(as) somos imparciais e facilitadores(as) do diálogo. Nós não podemos e nem estamos aqui para impor um acordo aos senhores, não somos juízes(as). Estamos aqui para tentar ajudá-los a identificar interesses e, se possível, retomar o diálogo, caso não haja.

Já participaram de alguma mediação? Já ouviram falar?

(Caso tenham participado: Embora já tenham participado de outra mediação, peço licença para explicar como será nossa forma de trabalho, porque pode ser que seja um pouco diferente do trabalho que vocês conheceram anteriormente).

A mediação tem como objetivo principal a retomada do diálogo, resgatar as boas relações, dar autoridade para os senhores solucionarem a questão trazida hoje.

Dessa forma, é importante dizer que é um procedimento informal, pois não há nenhuma regra de produção de provas. Mesmo assim, a participação dos advogados é de extrema importância para garantir a informação e direitos legais de todos. Além disso, nós não somos juízes(as), não podemos servir de prova ou testemunhas, caso deem andamento na ação.

Iniciaremos a fala com a parte autora e em seguida daremos o direito à fala para a parte requerida, ou seja, para a outra parte. Temos, também, a possibilidade de realizar sessões individuais, e aí, invertemos, a parte requerida começa e a parte autora se ausenta da sala por alguns instantes. Depois, por igual tempo, realizaremos a sessão individual, também com a parte autora. 
Pedimos aos senhores que respeitem a vez de falar de cada um, por isso temos papel e caneta na mesa. Caso lembrarem de alguma informação importante, podem anotar e depois daremos a oportunidade para falarem. Além disso, pedidos que respeitem uns aos outros, visto que este é um ambiente que preza pela boa relação e, mesmo que possa parecer difícil, tentamos sempre focar no futuro, pensamos que não há mais como mudar o que passou, então, o futuro é algo que está ao nosso alcance de mudar.

Como eu disse, não há obrigatoriedade de realizar acordo, caso haja acordo, ele será homologado pelo juiz, com valor de título executivo, isto é, um compromisso assumido pelos senhores que deverá ser cumprido conforme a lei, assim, encerra-se a ação.

Vale lembrar que o maior ganho de um acordo realizado na sessão de mediação é a escolha e satisfação das partes, sem precisar da imposição do juiz. Outro princípio que rege a mediação é a confidencialidade e, dessa forma, essa sessão não pode ser gravada. Nós mediadores(as) e observadores(as) não podemos falar nada a ninguém sobre o que conversaremos aqui dentro da sala; a única possibilidade da quebra de sigilo é no caso de ocorrer um eventual crime na sala, mas isso nunca aconteceu e acreditamos que com os senhores não será diferente.

Então, se precisarmos utilizar os papéis, eles serão rasgados e descartados ao final da audiência. No caso de precisarmos marcar uma segunda sessão de mediação, pediremos autorização para manter as anotações com intuito de facilitar e adiantar o trabalho na próxima sessão.

Assim, temos interesse em trabalhar conjuntamente com todos. Esperamos que não haja interrupções durante a fala do outro, que os senhores expliquem quais são seus interesses, sentimentos e necessidades; esperamos que considerem a perspectiva da outra parte, que tentem resolver o assunto, revelando informações importantes para todos aqui presentes.

Alguma dúvida?

Diante do que falamos, os senhores aceitam participar da mediação?

DECLARAÇÃO DE ABERTURA 2: resumida

Boa tarde, doutores(as). Sou , conciliador(a).

Muito obrigada pela presença de todos, tenho certeza de que se empenharam para estarem aqui.

Como os doutores(as) já conhecem o procedimento, peço licença para realizar uma breve declaração de abertura. 
É importante lembrar que estamos aqui com objetivo de pacificação social, almejando a possibilidade de um acordo, apesar disso, não são obrigados a realizá-lo. Quero lembrá-los, também, que a conciliação tem como base alguns princípios fundamentais, ao evidenciar, especialmente, a informalidade, confidencialidade, imparcialidade e neutralidade.

O tempo desta sessão pode chegar a trinta minutos. A fala inicial é da parte autora, em seguida passamos a fala para a parte requerida.

Alguma dúvida?

Os(as) senhores(as) aceitam participar da conciliação?

DECLARAÇÃO DE ABERTURA: para advogados e prepostos, com a presença de parte (civil comum)

Boa tarde, doutores(as). Sou , conciliador(a).

Muito obrigada pela presença de todos. Tenho certeza de que se empenharam para estarem aqui.

Como os doutores(as) já conhecem o procedimento, peço licença para realizar uma breve declaração de abertura, para explicar para a(s) parte(s) presente(s) como procederá esta sessão de conciliação.

É importante lembrar que estamos aqui com objetivo reestabelecer o diálogo, almejando a possibilidade de um acordo, porém, não são obrigados a realizá-lo. Quero lembrá-los, também, que a conciliação tem como base alguns princípios fundamentais, ao evidenciar, especialmente, a informalidade, confidencialidade, imparcialidade e neutralidade. Por estas razões, não podemos servir de testemunhas e nem provas, caso a ação continue em andamento.

O tempo desta sessão pode chegar a trinta minutos. A fala inicial é da parte autora, em seguida, passamos a fala para a parte requerida.

Alguma dúvida?

Os(as) senhores(as) aceitam participar da conciliação? 


\section{REFERÊNCIAS}

BARBOSA, Maria Lúcia Ferreira de Figueirêdo. Estratégias de polidez em respostas e elogias. Trabalhos em Linguística Aplicada. Campinas: Universidade Estadual de Campinas - Instituto de Estudos da Linguagem. Unicamp/SP, vol. 28, p. 5-18. Jul./Dez., 1996.

BARBOSA, Maria Lúcia Ferreira de Figueirêdo. Estratégias de polidez em respostas e elogios. Trabalhos em Linguística Aplicada. Campinas: Universidade Estadual de Campinas - Instituto de Estudos da Linguagem. Unicamp/SP, vol. 28, p. 5-18. Jul./Dez., 1996.

BRASIL. CONSELHO NACIONAL DE JUSTIÇA. Azevedo, André Gomma de (Org.). Manual de Mediação Judicial. 6ª Ed. (Brasília/DF:CNJ), 2016.

BROWN, Penelope; LEVINSON, Stephen C. Politeness. Some universals in language usage. 2ed. Cambridge. Cambridge University Press, 1987.

CASTILHO, Ataliba Teixeira. A língua falada no ensino de português. 8 ed. São Paulo: Contexto, 2014.

COSTA, Návia. Comunicação Jurídica: Linguagem, argumentação e gênero textual. $4^{\mathrm{a}}$ ed. Leme/SP: Mundo Jurídico, 2017.

DICIONÁRIO DE SINÔNIMOS online. Porto: 7Graus, 2019. Disponível em: https://www.sinonimos.com.br/. Acesso em: outubro/2019.

FÁVERO, Leonor L.; ANDRADE, Lúcia da C. V. de O.; AQUINO, Zilda G. O. de. Papéis discursivos e estratégias de polidez nas entrevistas de televisão. Veredas, Revista de Estudos Linguísticos, Juiz de Fora, v. 4, n. 1, p. 67 a 77, 2000.

FIORIN, José Luiz. A linguagem em uso. In: FIORIN, José Luiz. (org.). Introdução a Linguística: Objetos Teóricos. Volume I. São Paulo: Contexto, 2002, p. 165 - 185.

FRASER, Bruce. Conversation Mitigation. Journal os Pragmatics 4: 341-350, 1980.

GALEMBECK, Paulo de Tarso. Recursos de Expressividade em aulas. In: BURGO, Vanessa Hagemeyer; FERREIRA, Eduardo Francisco; STORTO, Letícia Jovelina. (orgs.). Análise de textos falados e escritos: aplicando teorias. Curitiba, PR: CRV, 2011.

GOFFMAN, Erving. Interaction ritual: essays on face-to-face behavior. New York: Anchor book, 1967.

GRICE, Herbert Paul. Lógica e Conversação. In: DASCAL, M. Fundamentos

Metodológicos da linguística. Pragmática. Campinas: Unicamp, 1982.

GÜLICH, E.; KOTSCHI, T. Les actes de reformulation dans la consultation La Dame de Caluire. IN: BANGE, P. (Org.). L'analyse dês interactions verbales - La Dame de Caluire: une consultation. Berna: Peter Lang, 1987, p. 15-81. 
HILGERT, José Gaston. Parafraseamento. In: JUBRAN, Clélia Spinardi (org.). A construção do texto falado - São Paulo: Contexto, 2015.

JUBRAN, Clélia Spinardi. Tópico discursivo. In: JUBRAN, Clélia Spinardi (org.). A construção do texto falado. São Paulo: Contexto, 2015.

KERBRAT-ORECCHIONI, Catherine. Análise da conversação: princípios e métodos. Tradução Carlos Piovezani Filho. São Paulo: Parábola Editorial, 2006.

KERBRAT-ORECCHIONI, Catherine. Análise da conversação: princípios e métodos. Tradução Carlos Piovezani Filho.- São Paulo: Parábola Editorial, 2006.

$\mathrm{KOCH}$, Ingedore Grunfeld Villaça. A inter-ação pela linguagem. 11. ed. São Paulo: Contexto, 2015.

KOCH, Ingedore Grunfeld Villaça. Argumentação e Linguagem. 13. ed. São Paulo: Cortez Editora, 2011.

KOCK, Ingedore Grunfeld Villaça. Escrever e Argumentar. Ingedore Grunfeld Villaça Kock e Vanda Maria Elias. São Paulo: Contexto, 2016a.

$\mathrm{KOCH}$, Ingedore Grunfeld Villaça. $\mathrm{O}$ texto e a construção dos sentidos. $10^{\mathrm{a}}$ ed. $4^{\mathrm{a}}$ reimpressão. São Paulo: Contexto, 2016 b.

KOCK, Ingedore Grunfeld Villaça. Introdução à linguística textual: trajetória e grandes temas. 2.ed. São Paulo: Contexto, 2017.

KOIKE, Dale A. Os frames culturais na fala: expectativas para a (des)cortesia. In: CABRAL, Ana Lúcia Tinoco; SEARA, Isabel Roboredo; GUARANHA, Manoel Francisco. (orgs.).

Descortesia e Cortesia: expressões de culturas. São Paulo: Cortez, 2017.

MARCUSCHI, Luiz Antônio. Análise da conversação. 5.ed. São Paulo: Ática, 1986.

MARCUSCHI, Luiz Antônio. Hesitação. In: JUBRAN, Clélia Spinardi (org.). A construção do texto falado. São Paulo: Contexto, 2015.

MARCUSCHI, Luiz Antônio. Repetição. In: JUBRAN, Clélia Spinardi (org.). A construção do texto falado. São Paulo: Contexto, 2015.

MEIRELLES, Sueli. Linguística para mediação de conflitos: pessoais, familiares, profissionais e sociais. Nova Friburgo: Edição do Autor, 2017. (n.p)

MOORE, Christopher W. O processo de mediação: estratégias práticas para a resolução de conflitos. Trad. Magda França Lopes. 2a . Ed. Porto Alegre: Artmed, 1998.

MORRISON, Jean. A linguagem da girafa: um passeio divertido pelos fundamentos da comunicação não-violenta. São José dos Campos: Colibri, 2019. 
RISSO, Mercedes Sanfelice; OLIVEIRA E SILVA, Giselle Machline; URBANO, Hudinilson. Traços Definidores dos Marcadores Discursivos. In: JUBRAN, Clélia Spinardi (org.). A construção do texto falado. São Paulo: Contexto, 2015.

ROSENBERG, Marshall B. Comunicação não-violenta: técnicas para aprimorar relacionamentos pessoais e profissionais. São Paulo: Ágora, 2006.

SACKS, Harvey; SCHEGLOFF, Emanuel A; JEFFERSON, Gail. A Simplest Systematics for the Organization of Turn Taking for Conversation. Language, v. 50, n. 4, p. 696-735, 1974.

SLOBIN, Dan Isaac. Psicolinguística. São Paulo: Ed. Nacional: Ed. Da Universidade de São Paulo, 1980.

SOUZA-E-SILVA, Maria Cecília; CRESCITELLI, Mercedes Canha. Interrupção. In: JUBRAN, Clélia Spinardi (org.). A construção do texto falado - São Paulo: Contexto, 2015.

TAKAHASHI, Bruno et al. Manual de mediação e conciliação na Justiça Federal. Brasília: Conselho da Justiça Federal, 2019.

URBANO, Hudinilson Variedades de planejamento no texto falado e no texto escrito. In: PRETI, Dino (Org.). Estudos de língua falada: variações e confrontos. São Paulo: São Paulo: Humanitas/FFLCH/USP, 1998. p. 131-152. (Projetos Paralelos, 3).

WEIL, Pierre. O corpo fala: a linguagem silenciosa da comunicação não verbal. 68. Ed. Petrópolis: Vozes, 2011. 


\section{A AUTORA}

Claudia Poliana de Escobar de Araujo graduou-se em Letras pela Universidade Federal de Mato Grosso do Sul - Três Lagoas/MS. Mestre e doutoranda (bolsista capes) em Letras - Estudos Linguísticos pela Universidade Federal de Mato Grosso do Sul - Três Lagoas/MS. Atuou como docente na Educação Básica das Redes Estadual e Privada de Ensino de Mato Grosso do Sul e na Educação Superior na Universidade Federal de Mato Grosso do Sul - Três Lagoas/MS. Tem experiência na área de Letras, com ênfase em Língua Portuguesa, atuando principalmente nos seguintes temas: Análise da Conversação, Estratégia Comunicativa, Língua Falada, Pragmática e Linguística Forense. Mediadora/Conciliadora judicial em formação. 